\title{
Differential climate impacts for policy-relevant limits to global warming: the case of $1.5^{\circ} \mathrm{C}$ and $2{ }^{\circ} \mathrm{C}$
}

\author{
Carl-Friedrich Schleussner ${ }^{1,2}$, Tabea K. Lissner ${ }^{1,2}$, Erich M. Fischer ${ }^{3}$, Jan Wohland ${ }^{2}$, Mahé Perrette ${ }^{2}$, \\ Antonius Golly ${ }^{4,6}$, Joeri Rogelj ${ }^{3,5}$, Katelin Childers ${ }^{2}$ Jacob Schewe $^{2}$, Katja Frieler ${ }^{2}$, Matthias Mengel ${ }^{1,2}$, \\ William Hare $^{1,2}$, and Michiel Schaeffer ${ }^{1,7}$ \\ ${ }^{1}$ Climate Analytics, Friedrichstr. 231 - Haus B, 10969 Berlin, Germany \\ ${ }^{2}$ Potsdam Institute for Climate Impact Research, Potsdam, Germany \\ ${ }^{3}$ Institute for Atmospheric and Climate Science, ETH Zurich, Zurich, Switzerland \\ ${ }^{4}$ GFZ German Research Centre for Geosciences, Potsdam, Germany \\ ${ }^{5}$ Energy Program, International Institute for Applied Systems Analysis, Laxenburg, Austria \\ ${ }^{6}$ University of Potsdam, Institute of Earth and Environmental Science, Potsdam, Germany \\ ${ }^{7}$ Wageningen University and Research Centre, Environmental Systems Analysis Group, \\ Wageningen, the Netherlands
}

Correspondence to: Carl-Friedrich Schleussner (carl.schleussner@ climateanalytics.org)

Received: 8 October 2015 - Published in Earth Syst. Dynam. Discuss.: 27 November 2015

Revised: 31 March 2016 - Accepted: 7 April 2016 - Published: 21 April 2016

\begin{abstract}
Robust appraisals of climate impacts at different levels of global-mean temperature increase are vital to guide assessments of dangerous anthropogenic interference with the climate system. The 2015 Paris Agreement includes a two-headed temperature goal: "holding the increase in the global average temperature to well below $2{ }^{\circ} \mathrm{C}$ above pre-industrial levels and pursuing efforts to limit the temperature increase to $1.5^{\circ} \mathrm{C}$ ". Despite the prominence of these two temperature limits, a comprehensive overview of the differences in climate impacts at these levels is still missing. Here we provide an assessment of key impacts of climate change at warming levels of $1.5^{\circ} \mathrm{C}$ and $2{ }^{\circ} \mathrm{C}$, including extreme weather events, water availability, agricultural yields, sea-level rise and risk of coral reef loss. Our results reveal substantial differences in impacts between a $1.5^{\circ} \mathrm{C}$ and $2{ }^{\circ} \mathrm{C}$ warming that are highly relevant for the assessment of dangerous anthropogenic interference with the climate system. For heat-related extremes, the additional $0.5^{\circ} \mathrm{C}$ increase in global-mean temperature marks the difference between events at the upper limit of present-day natural variability and a new climate regime, particularly in tropical regions. Similarly, this warming difference is likely to be decisive for the future of tropical coral reefs. In a scenario with an end-of-century warming of $2{ }^{\circ} \mathrm{C}$, virtually all tropical coral reefs are projected to be at risk of severe degradation due to temperature-induced bleaching from 2050 onwards. This fraction is reduced to about $90 \%$ in 2050 and projected to decline to $70 \%$ by 2100 for a $1.5^{\circ} \mathrm{C}$ scenario. Analyses of precipitation-related impacts reveal distinct regional differences and hot-spots of change emerge. Regional reduction in median water availability for the Mediterranean is found to nearly double from $9 \%$ to $17 \%$ between $1.5^{\circ} \mathrm{C}$ and $2{ }^{\circ} \mathrm{C}$, and the projected lengthening of regional dry spells increases from 7 to $11 \%$. Projections for agricultural yields differ between crop types as well as world regions. While some (in particular high-latitude) regions may benefit, tropical regions like West Africa, South-East Asia, as well as Central and northern South America are projected to face substantial local yield reductions, particularly for wheat and maize. Best estimate sea-level rise projections based on two illustrative scenarios indicate a $50 \mathrm{~cm}$ rise by 2100 relative to year 2000 -levels for a $2{ }^{\circ} \mathrm{C}$ scenario, and about $10 \mathrm{~cm}$ lower levels for a $1.5^{\circ} \mathrm{C}$ scenario. In a $1.5^{\circ} \mathrm{C}$ scenario, the rate of sea-level rise in 2100 would be reduced by about $30 \%$ compared to a $2{ }^{\circ} \mathrm{C}$ scenario. Our findings highlight the importance of regional differentiation to assess both future climate risks and different vulnerabilities to incremental increases in globalmean temperature. The article provides a consistent and comprehensive assessment of existing projections and
\end{abstract}


a good basis for future work on refining our understanding of the difference between impacts at $1.5^{\circ} \mathrm{C}$ and $2{ }^{\circ} \mathrm{C}$ warming.

\section{Introduction}

Recent decades have seen increasing climate impacts, many of which science is now able to attribute to anthropogenic carbon dioxide emissions and consequent global warming (IPCC, 2013; King et al., 2015). On-going temperature increase will escalate these impacts on ecological and human systems (IPCC, 2014a), which has made climate change a political issue of central importance. The response of the global community to that challenge laid out in the Paris Agreement under the United Nations Framework Convention on Climate Change (UNFCCC) provides a promising framework for global climate protection (UNFCCC, 2015). Specifically, the Agreement includes two long-term global goals (LTGGs): "holding the increase in the global average temperature to well below $2{ }^{\circ} \mathrm{C}$ above pre-industrial levels and pursuing efforts to limit the temperature increase to $1.5^{\circ} \mathrm{C}$, recognizing that this would significantly reduce the risks and impacts of climate change". LTGGs have been proven useful to guide climate action (SED, 2015) and their inclusion aims to operationalize the "ultimate objective" of the UNFCCC of a "stabilization of greenhouse gas concentrations in the atmosphere at a level that would prevent dangerous anthropogenic interference with the climate system" (UNFCCC, 1992). Although the assessment of levels of dangerous interference is primarily a political process that requires value judgements and depends on different world views (Knutti et al., 2015), it needs to be informed by the best available science outlining the impacts of climate change and mitigation efforts implied by different LTGGs. Based on the Fifth Assessment Report (AR5) of the Intergovernmental Panel on Climate Change (IPCC), a recent expert assessment focussing on the adequacy of the LTGGs in light of the ultimate objective of the convention concluded that "significant climate impacts are already occurring [...] and additional magnitudes of warming will only increase the risk of severe, pervasive and irreversible impacts" (SED, 2015). While the report emphasized that a warming of global mean surface air temperature (GMT) of $2{ }^{\circ} \mathrm{C}$ above pre-industrial levels should not be seen as a "safe" level, it also concluded that substantial research gaps exist regarding the differences in climate impacts between a $1.5^{\circ} \mathrm{C}$ and $2{ }^{\circ} \mathrm{C}$ temperature increase (SED, 2015). In particular, comprehensive, multisectoral assessments of differences in climate impacts between a $1.5^{\circ} \mathrm{C}$ and $2{ }^{\circ} \mathrm{C}$ warming are lacking. The assessment of such differences would greatly profit from a regional and impact centred approach that allows for a more differentiated picture than globally aggregated metrics (Seneviratne et al., 2016). For example, changes in the hydrological cycle as a result of temperature increase will be regionally dependent (Held and Soden, 2006).

The "Turn down the heat" report series issued by the World Bank (Schellnhuber et al., 2012, 2013, 2014) assessed climate risks for a $2{ }^{\circ} \mathrm{C}$ and a $4{ }^{\circ} \mathrm{C}$ warming above preindustrial levels for different world regions. The report of the Working Group 2 (WG2) of the IPCC AR5 includes both, impact and region specific chapters, and provides warming level dependent information on impacts where available. The range of emission scenarios which provide the basis for the climate impact projections in the IPCC AR5, the Representative Concentration Pathways (RCPs), however, do not allow for a straightforward differentiation between impacts for warming levels of $1.5^{\circ} \mathrm{C}$ and $2^{\circ} \mathrm{C}$. Only the lowest emission pathway RCP2.6 is in line with keeping GMT increase above pre-industrial levels to below $2{ }^{\circ} \mathrm{C}$ with a likely chance $(66 \%$ probability, IPCC, 2013) and no pathway in line with a $1.5^{\circ} \mathrm{C}$ limit is assessed in the AR5. Still, the IPCC AR5 WG2 report provides an expert assessment of key impacts at different levels of warming, summarized in five "Reasons-for-Concern" (RFCs, Oppenheimer et al., 2014). The risks for three out of five of these RFCs are assessed as at least moderate at $1.5^{\circ} \mathrm{C}$ GMT increase above pre-industrial levels, and as at least moderate-high at $2{ }^{\circ} \mathrm{C}$. In the RFC framework, moderate risks imply that associated impacts are both detectable and attributable to climate change with at least medium confidence, whereas high risks are associated with severe and widespread impacts (Oppenheimer et al., 2014). Among the three RFCs that show high risks at $2{ }^{\circ} \mathrm{C}$ are Risks to unique and threatened systems (RFC1) that include coral reefs and other highly vulnerable human systems as well as ecosystems, Risks associated with extreme weather events (RFC2) and Risks associated with the distribution of impacts (RFC3).

Based on the Coupled Model Intercomparison Project 5 (CMIP5, Taylor et al., 2011) and the Inter-Sectoral Impact Model Intercomparison Project (ISI-MIP, Warszawski et al., 2014), this article provides an extensive assessment of regionally differentiated climate impacts at levels of $1.5^{\circ} \mathrm{C}$ and $2{ }^{\circ} \mathrm{C}$ GMT increase above pre-industrial levels (henceforth $1.5^{\circ} \mathrm{C}$ and $2{ }^{\circ} \mathrm{C}$ ) for different climate impacts, including increases in extreme weather events (Sect. 3), changes in water availability (Sect. 4), crop yield projections (Sect. 5), sealevel rise (SLR, Sect. 6) and coral reef degradation (Sect. 7).

The following Sect. 2 outlines our methods for the assessment of changes in extreme weather indices, water availability and agricultural impacts. Analyses of sea-level rise and impacts on coral reefs contain additional details on sectorspecific methods. Where impact-specific additional methodological specifications are needed, these are given in the re- 
spective section, followed by a presentation of the main results and a short discussion. A summarizing discussion and conclusions finalize this contribution in Sect. 8. The Supplement (SM) provides additional methodological information as well as further impact maps, regional overviews and summary tables.

\section{Methods}

This section provides an overview of the methods applied for the assessment of extreme weather indices, water availability and agricultural impacts. The individual subsections provide additional information on sector- and impact-specific methods as well as on the data analysed. The meteorological extreme indices are derived from an ensemble of general circulation models (GCMs) from CMIP5 (Taylor et al., 2011) while our assessment of water availability and agricultural impacts at $1.5^{\circ} \mathrm{C}$ and $2{ }^{\circ} \mathrm{C}$ is based on the ISI-MIP Fast Track data (Warszawski et al., 2014; Frieler et al., 2015).

For both data archives, the impacts for a GMT increase of 1.5 and $2{ }^{\circ} \mathrm{C}$ above pre-industrial levels are derived for 20 -year time slices with the respective mean warming for each model separately. To account for model deviations from observations over the historical period, the warming levels are derived relative to the reference period 1986-2005, (this reference period is $0.6^{\circ} \mathrm{C}$ warmer than pre-industrial levels (1850-1900), IPCC, 2013), which translates to a warming of $0.9^{\circ} \mathrm{Cand} 1.4^{\circ} \mathrm{C}$ above reference period levels for the $1.5^{\circ} \mathrm{C}$ and $2{ }^{\circ} \mathrm{C}$ limit, respectively. All time slices are derived from the RCP8.5 scenario (the time slices for the individual GCMs are given in the SM Table S1). 1986-2005 is also the common reference period to assess projected changes in extreme indices and climate impacts.

All our results are calculated with respect to this common reference period. For consistency with the respective policy targets, however, we express the GMT differences of $0.9^{\circ} \mathrm{C}$ and $1.4^{\circ} \mathrm{C}$ by their implied pre-industrial warming of $1.5^{\circ} \mathrm{C}$ and $2{ }^{\circ} \mathrm{C}$.

Analysing time-slices centred around a specific level of warming relies on the assumption that the changes in the climate and climate impact signals studied here are dominantly driven by changes in GMT and that the effect of changes in time-lagged systems such as large-scale ocean circulations (Schleussner et al., 2014a, b) on the quantities studied are of minor importance. In addition, this approach does not account for the effect of other anthropogenic climate forcers that may differ for the same level of total radiative forcing such as aerosols (Zopa et al., 2013). It comes, however, also with several advantages. In particular, it eliminates the spread due to different transient climate responses across the model ensemble, which can deviate by up to a factor of two (Flato et al., 2013). Traditional approaches that analyse impacts over a given time period for all models in a model ensemble and relate this to a me- dian GMT increase across the model ensemble do not account for this ensemble-intrinsic spread of global warming levels and will consequently overestimate the ensemble uncertainty of the GMT-dependent indices studied. The timeslice approach has furthermore been shown to provide better accuracy than traditional pattern scaled approaches (Herger et al., 2015). Although also relying on the debatable assumption of scenario-independence of the projected signals, which does not fully hold in climate stabilization scenarios (Tebaldi and Arblaster, 2014), time-slicing avoids known short-comings of classical pattern scaling analysis. In particular, it allows one to capture non-linearities in extreme indices and precipitation-related signals that relate to nonlinear local feedbacks (Lopez et al., 2013) or large-scale circulation changes (Chadwick and Good, 2013; Hawkins et al., 2014).

In addition to the anthropogenic forcing, natural variability is a dominant driver of the climate signal on multi-annual timescales for time-averaged quantities such as mean temperature and precipitation change (Knutti and Sedláček, 2012; Marotzke and Forster, 2014) and in particular for extreme weather events (Kendon et al., 2008; Tebaldi et al., 2011). Thus, natural variability may mask an already present climate change signal and consequently lead to a delayed detection of the imprints of climate change (Tebaldi and Friedlingstein, 2013). To overcome this limitation, Fischer et al. (2013) proposed a spatial aggregation approach that allows for a robust detection of an anthropogenic footprint in climatic extremes despite natural variability - an approach that has also been successfully applied to the observational record (Fischer and Knutti, 2014). Here we adopt and extend this spatial aggregation approach.

As in Fischer et al. (2013), we consider the distribution of changes in the selected impact indicator at each grid point over the global land-mass between $66^{\circ} \mathrm{N}$ and $66^{\circ} \mathrm{S}$ (henceforth referred to as global land-mass) and additionally analyse changes for 26 world regions (as used in IPCC, 2012, see Table 1 for details). This yields distributions for the indicators at $1.5^{\circ} \mathrm{C}$ and $2{ }^{\circ} \mathrm{C}$ and for each of the ensemble members and regions, where the sample size is given by the number of grid points included in the respective regions. In a next step, the statistical significance of differences between the 1.5 and $2{ }^{\circ} \mathrm{C}$ distributions is assessed for each region and ensemble member. This is done using a two-sample KolmogorovSmirnov (KS) test with the null hypothesis that both distributions for $1.5^{\circ} \mathrm{C}$ and $2{ }^{\circ} \mathrm{C}$ are drawn from the same probability distribution.

A rejection of the test's null-hypothesis at a significance level of $95 \%$ is taken as a robust difference in projections between these two warming levels. This pairwise test, based on the individual model ensemble members analysed, allows for robust statements about differences between the two warming levels, even if there is substantial overlap of uncertainty bands in the model ensemble. For GCMs that provide multiple realizations, the distributions are combined for 
Table 1. Overview of the world regions used as well as the respective acronyms based on IPCC (2012). Please note that the Central American (CAM) region has been extended eastwards to also include the Caribbean.

\begin{tabular}{llll}
\hline ALA & Alaska, North-West Canada & NEB & North-East Brazil \\
AMZ & Amazon & NEU & Northern Europe \\
CAM & Central America, Mexico, Caribbean & SAF & South Africa \\
CAS & Central Asia & SAH & Sahara \\
CEU & Central Europe & SAS & South Asia \\
CGI & East Canada, Greenland, Iceland & SAU & South Australia, New Zealand \\
CNA & Central North America & SEA & South-East Asia \\
EAF & East Africa & SSA & South-East South America \\
EAS & East Asia & TIB & Tibetan Plateau \\
ENA & East North America & WAF & West Africa \\
MED & Mediterranean & WAS & West Asia \\
NAS & North Asia & WNA & West North America \\
NAU & North Australia & WSA & West Coast South America \\
\hline
\end{tabular}

each warming level leading to larger samples and higher discriminatory power of the KS test. Please note that this approach is only applied for the KS test and not for the ensemble projections. For the latter, the averaged signal over multiple realizations of a single GCM is included in the ensemble analysis ensuring equal weight to all GCMs investigated (see SM Sect. 1 for further details on the methods and the treatment of multiple realizations). A similar approach has been applied recently to investigate the timing of anthropogenic emergence in simulated climate extremes (King et al., 2015).

Based on the regionally specific distributions, cumulative density functions (CDF) of changes in the impact indices over the land area of the respective region are derived. As in Fischer et al. (2013), we fit a probability density function to the empirical distribution of the climate signal using a Gaussian kernel density estimator. Individual gridcells are weighted according to their latitude-dependent area. These CDFs are derived for each ensemble member (GCM or GCM-impact model combination) and the ensemble median as well the likely range ( $66 \%$ of the ensemble members are within this range) are given. This land-area focused approach allows to directly assess not only the median change over a region, but also changes for smaller fractions of the land area. At the same time, the uncertainty estimates based on the model ensemble spread can be directly visualized.

\section{Extreme weather events}

There is a growing body of evidence showing that the frequency and intensity of many extreme weather events has increased significantly over the last decades as a result of anthropogenic climate change, but confidence in the significance of the trend and attribution to anthropogenic origin differ substantially between types of extreme weather events and regions (IPCC, 2013). With on-going warming, these trends are projected to continue (IPCC, 2012). Impacts of extreme weather events will particularly, but not exclusively, affect the most vulnerable with the lowest levels of adaptive capacity and represent one of the biggest threats posed by climate change (IPCC, 2014b). In this Section, the difference in impacts between a warming of $1.5^{\circ} \mathrm{C}$ and $2{ }^{\circ} \mathrm{C}$ for four different types of meteorological extreme event indices are assessed. Good agreement between the CMIP5 model ensemble median estimates of extreme event indices including the four indices investigated here and observational data sets has been reported by Sillmann et al. (2013a). The indices used follow the recommendations of the Expert Team on Climate Change Detection and Indices (Zhang et al., 2011) and are derived on an annual basis:

- Intensity of hot extremes (TXx): annual maximum value of daily maximum temperature.

- Warm spell duration indicator (WSDI): annual count of the longest consecutive period in which the daily maximum temperature for each day exceeds the $90 \%$ quantile for this day over the reference period. The minimum length is 6 consecutive days.

- Dry spell length or consecutive dry days (CDD): annual maximum number of consecutive days for which the precipitation is below $1 \mathrm{~mm}$ per day.

- Heavy precipitation intensity or maximum accumulated 5-day precipitation (RX5day): absolute annual maximum of consecutive 5-day precipitation.

\subsection{Methods and data}

Projected changes in climate extreme indices are assessed using an ensemble of 11 CMIP5-models for TXx and WSDI and 14 for RX5day and CDD and follows the methods outlined in Sect. 2. The model selection was done based on data availability. All available GCMs are assessed on a uniform grid with a $2.5^{\circ} \times 1.9^{\circ}$ resolution. Multiple realizations of scenario runs for individual models are included when available, and in that case allow to estimate CDFs for natural 
variability that are derived based on pairwise realizations of model runs over the reference period (see SM Sect. 1.2 for further detail on the methodology applied).

We assess the changes in TXx and WSDI for a warming of 1.5 and $2{ }^{\circ} \mathrm{C}$ and derive changes of 20 -year averages of extreme indices for the model-dependent warming-level timeslices at each land grid point relative to the 1986-2005 reference period. Changes in precipitation-related indices are described as relative changes while we consider absolute changes for the other indicators. For the CDF analysis for TXx, the absolute signal is normalized by the standard deviation over the reference period.

\subsection{Results}

\subsubsection{Heat extremes}

Substantial increases of $3^{\circ} \mathrm{C}$ and more in TXx over large parts of the Northern Hemisphere, central South America and South Africa as well as increases in warm-spell durations (WSDI) of 3 months and more are projected under a warming of $2{ }^{\circ} \mathrm{C}$. Figure 1 depicts changes in TXx (left panels) and WSDI (right panels) for a $1.5^{\circ} \mathrm{C}$ (top panels) and $2{ }^{\circ} \mathrm{C}$ (middle panels) GMT temperature increase, as well as the differences between the two warming levels (bottom panels) on a grid-cell basis. Particularly strong increases in WSDI are found in some tropical coastal areas, which we attribute to a large share of ocean surface in the respective grid cells that lead to an amplification of the effect compared to pure land grid cells and should not be over-interpreted. We correct for this potential spurious amplification by excluding all grid-cells with a WSDI greater than 150 days under $2{ }^{\circ} \mathrm{C}$ from the $\mathrm{CDF}$ analysis for the respective regions. The majority of GCMs agree on a robust increase in these heat-related indices and show significant differences between the two warming levels. The impacts are robustly smaller at $1.5^{\circ} \mathrm{C}$ warming in both cases (see results for the KS test listed in Table S2).

Globally and regionally resolved CDFs for TXx, normalized to the standard deviation $(\sigma)$ over the reference period, are given in Fig. 2 and median values are listed in Table S2. $50 \%$ of the global land-mass will experience a median TXx increase of more than 1.2 (1.8) SD (standard deviations) relative to the reference period for a warming of $1.5^{\circ} \mathrm{C}\left(2{ }^{\circ} \mathrm{C}\right)$ above pre-industrial levels. The regional assessments indicate that the tropical regions in Africa, South America and South-East Asia are projected to experience the strongest increase in land area covered by heat extremes relative to the regional natural variability, where 3- $\sigma$ events become the new normal under a $2{ }^{\circ} \mathrm{C}$ warming.

The pattern of a strong tropical signal is mainly due to the small natural variability of TXx in tropical regions. This is also apparent for the WSDI CDFs resolved in Fig. 3. For a warming of $1.5^{\circ} \mathrm{C}$, a median increase in WSDI length by about 1 month is projected for $50 \%$ of the global land area that increases by $50 \%$ for a $2{ }^{\circ} \mathrm{C}$ warming. Since this index is derived relative to natural variability over a reference period, the signal again is greatly amplified in tropical regions, where a median WSDI of up to 3 months is projected for Amazonia, East and West Africa and South-East Asia (see Table S2). Given that the WSDI only measures the longest consecutive interval, such an increase can be interpreted as entering a new climate regime for these tropical regions (Diffenbaugh and Scherer, 2011; Mora et al., 2013; King et al., 2015).

A meaningful assessment of impacts requires not only an assessment of absolute changes, but these also have to be interpreted in the light of regional climate conditions. It is the regional natural climate variability that arguably determines a "climate normal" to which human systems as well as ecosystems might be adapted to Hansen et al. (2012) and Coumou and Robinson (2013). While this may hold as a general assumption for a range of impacts concerning human health as well as ecosystems, it is important to note that the severity of certain climate impacts may also depend on the exceedance of absolute thresholds, as has been shown for temperature effects on crop yields, for example (Deryng et al., 2014; Smith et al., 2014). The choice of an either relative or absolute representation of changes in climate impacts thus has to be made in light of the impact of interest. In addition, a normalization by the standard deviation similar to the one applied here has been shown to introduce statistical biases arising from a limited sample size of the reference period (Sippel et al., 2015) that we do not account for in the results presented here.

Our findings are in line with previous assessments of projected changes in extreme temperatures and heat-waves (Orlowsky and Seneviratne, 2012; Sillmann et al., 2013b; Kharin et al., 2013) and illustrate the substantial increase in the likelihood of heat extremes between 1.5 and $2{ }^{\circ} \mathrm{C}$ warming above pre-industrial levels, in particular when putting these changes in perspective to regional natural climate variability (Diffenbaugh and Scherer, 2011; Coumou and Robinson, 2013).

\subsection{Extreme precipitation and dry spells}

Uncertainty in model projections of precipitation extremes is considerably larger than that of temperature-related extremes. Figure 4 depicts the median projections for RX5day (Maximum accumulated 5-day precipitation, left panels) and CDD (Dry spell length, right panels), which exhibit contrasting patterns in terms of signal strength and robustness. The KS test illustrates the additional merit of a regional analysis of precipitation-related extremes (see Table S3). While all models in the ensemble indicate a robust difference between a 1.5 and $2{ }^{\circ} \mathrm{C}$ warming for both indices for the global land mass, the analysis for the separate world regions reveals different patterns.

A robust indication (more than $66 \%$ of the models reject the null hypothesis of the KS test at the $95 \%$ significance level, see Table S3) of a difference in RX5day is projected 

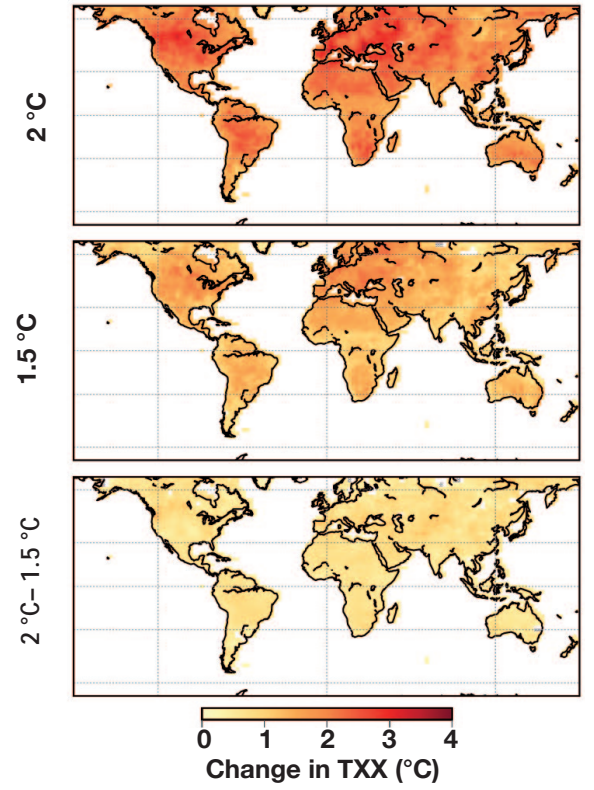
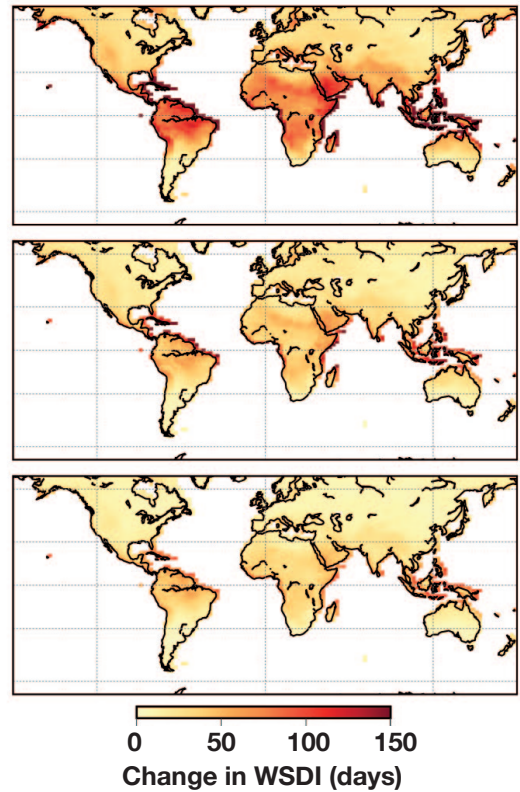

Figure 1. Median changes of TXx (left panels) and WSDI (right panels) for a warming of $2{ }^{\circ} \mathrm{C}$ (upper panels), $1.5^{\circ} \mathrm{C}$ (middle panels) and the difference between the two warming levels (lower panels). Changes in TXx are given in ${ }^{\circ} \mathrm{C}$, whereas changes in WSDI are given in days.

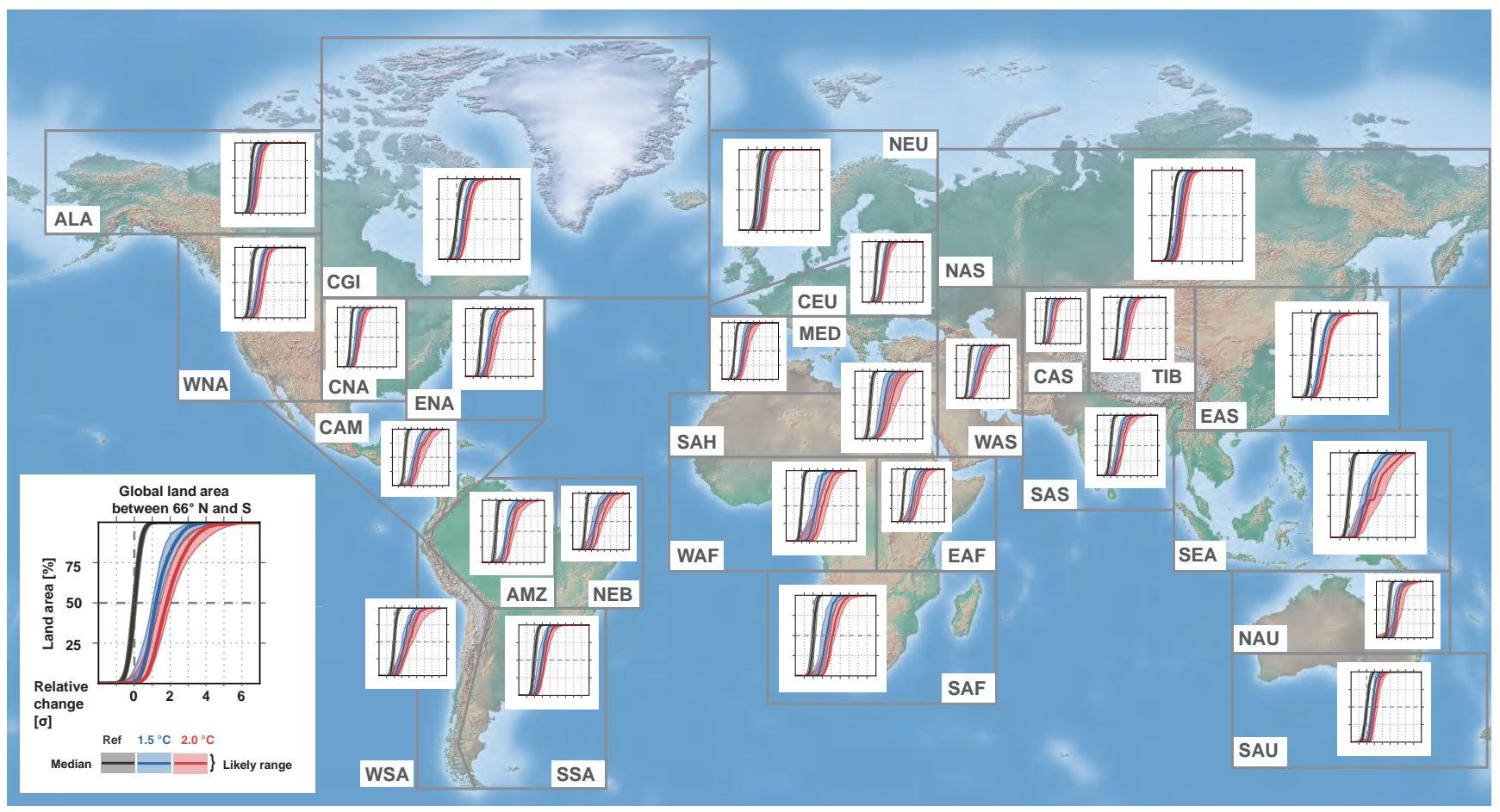

Figure 2. CDFs for projected regional aggregated changes in TXx (relative to the standard variation over the reference period) for the global land area between $66^{\circ} \mathrm{N}$ and $66^{\circ} \mathrm{S}$ (lower left corner) as well as resolved for 26 world regions separately (see Sect. 2 for further details). The graph axes are the same for all panels. Changes are given relative to the standard deviation over the 1986-2005 reference period. Note that a change in 2 (3) SD (standard deviations) implies that events with a reference return time of several decades (centuries) become the new normal, whereas a new normal of $4 \sigma$ refers to an event that would be extremely unlikely to occur in a reference period climate. Region impact overviews are provided in the Supplement. 


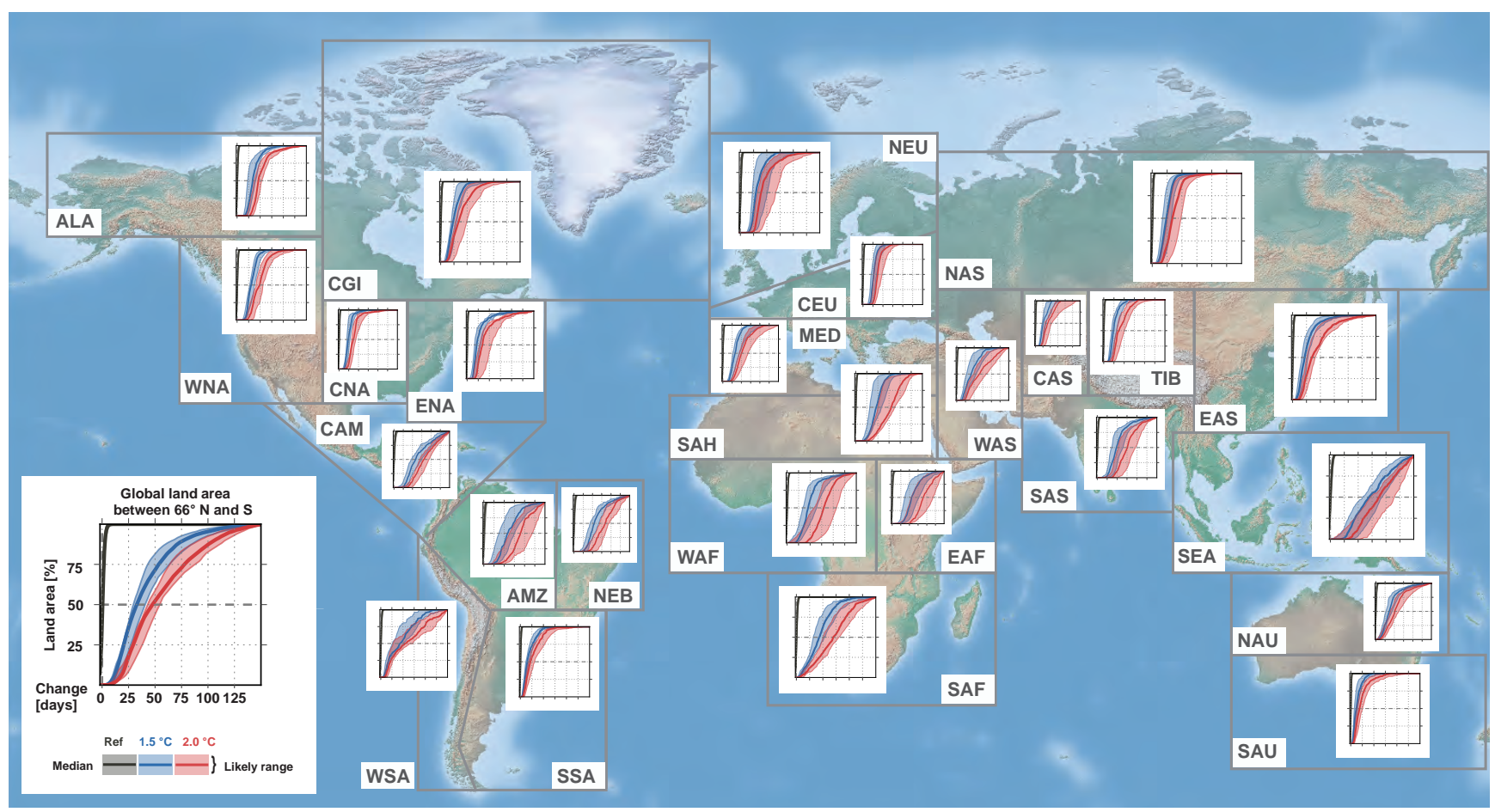

Figure 3. Same as Fig. 2, but for WSDI in days.
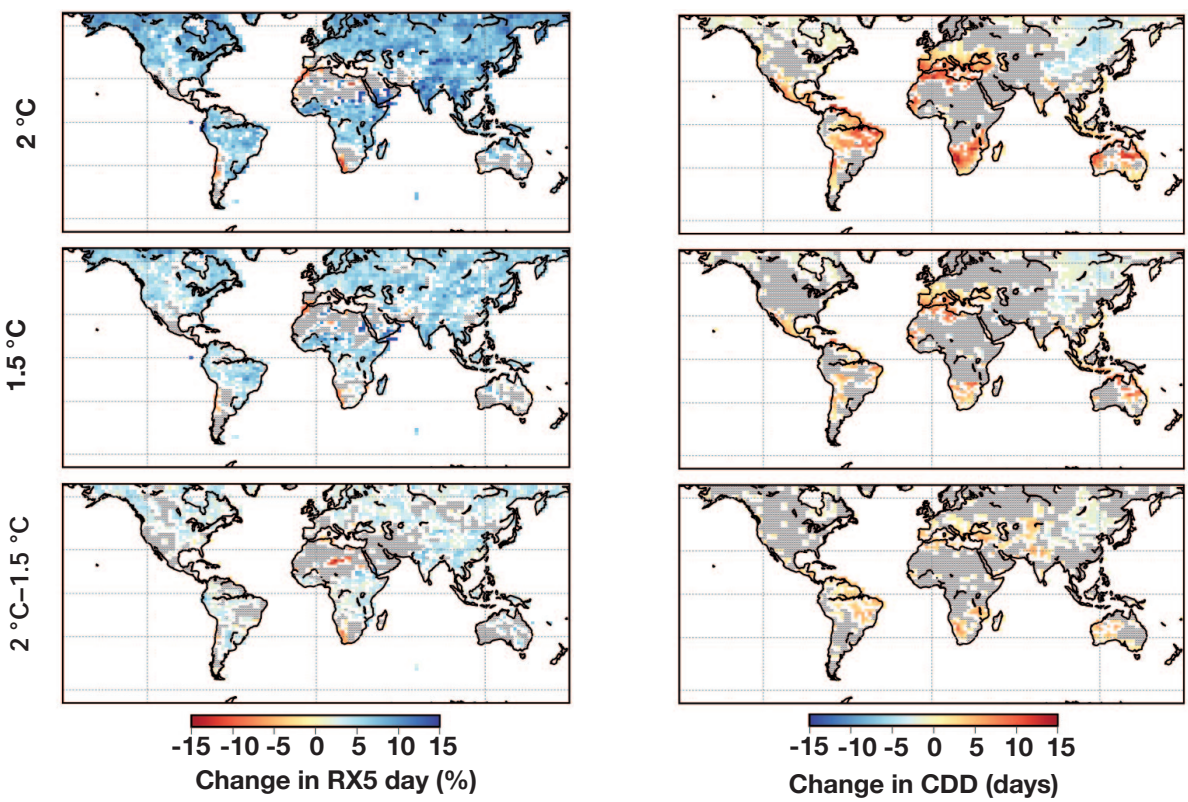

Figure 4. Same as Fig. 1, but for RX5day and CDD. Hatched areas indicate regions, where less than $66 \%$ of the models in the ensemble agree with the sign of change of the median projections.

in particular for the high northern latitude regions, East Asia, as well as East and West Africa. While the high northern latitudes are also among those regions experiencing the largest increase in RX5day between the assessed warming levels (up to 7 and $11 \%$, median estimates for $1.5^{\circ} \mathrm{C}$ and $2{ }^{\circ} \mathrm{C}$, respec- tively), projections for other regions that experience a considerable increase under a $1.5^{\circ} \mathrm{C}$ warming do not indicate a significant difference between the warming levels. This is in particular noteworthy for the Amazon region and North-East Brazil, where precipitation extremes are likely related to the 


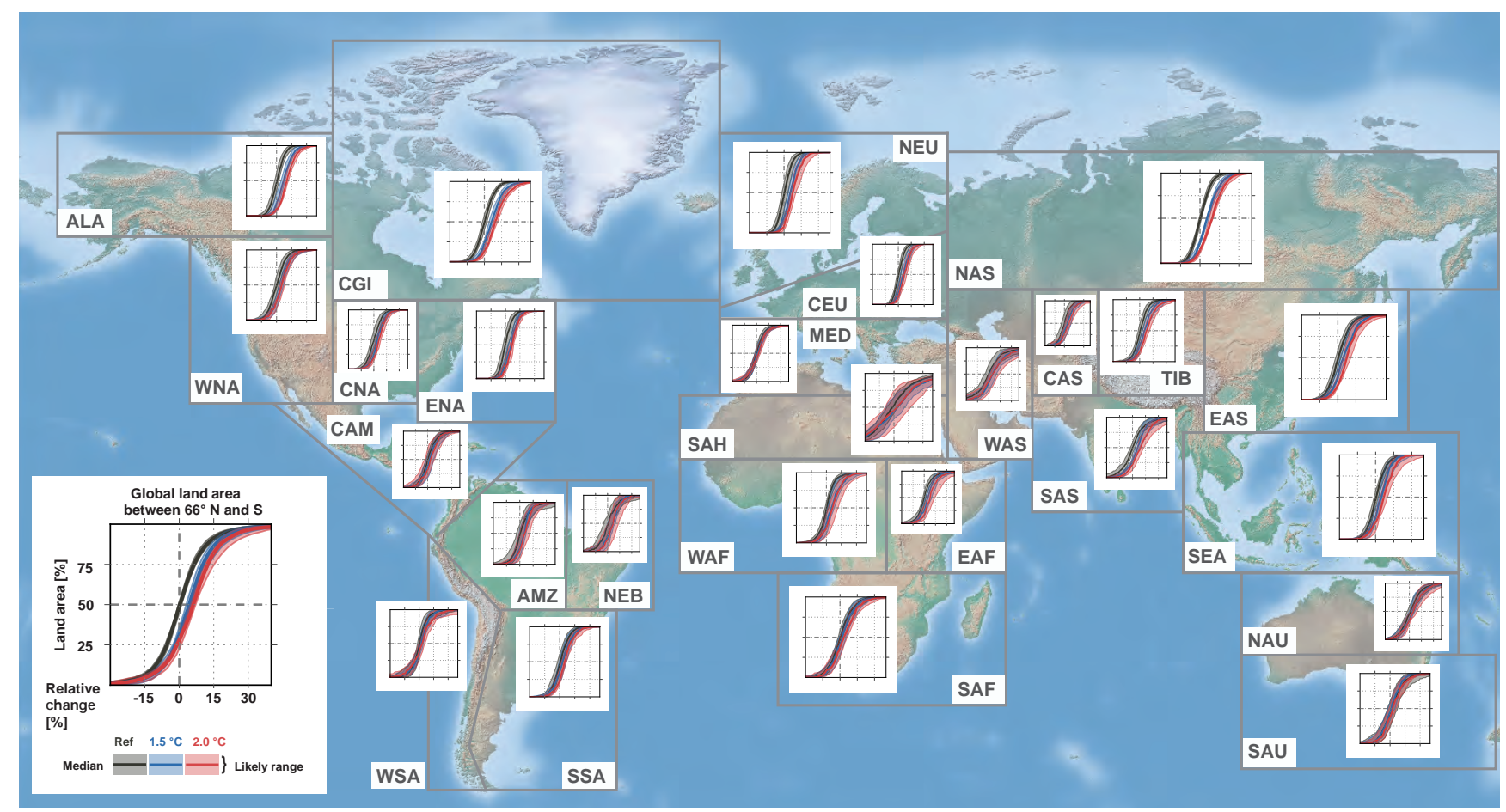

Figure 5. Same as Fig. 2 but for RX5day. Changes are given relative to the 1986-2005 reference period.

South American monsoon systems (Boers et al., 2014) and to a lesser extent for West Africa (see Fig. 5 and Table S3).

A different picture emerges for CDD as an indicator for dry spell length. For the majority of the global land area, little to no differences in CDD are projected relative to the reference period (see Fig. 4). However, about $40 \%$ of the global land area in the subtropical and tropical regions experience an increase in CDD length, including the Mediterranean, Central America, the Amazon as well as South Africa (compare Fig. 4 and Fig. 6). In these regions, the KS test also reveals robust indications for differences in impacts between 1.5 and $2{ }^{\circ} \mathrm{C}$. This difference is particularly pronounced for the Mediterranean region, where the median CDD length increases from $7 \%$ (likely range 4 to $10 \%$ ) to $11 \%$ (likely range 6 to $15 \%$ ) between $1.5^{\circ} \mathrm{C}$ and $2{ }^{\circ} \mathrm{C}$.

It is important to highlight that CDD is only an indicator for dry spell length and does not account for changes in evapotranspiration and soil-moisture related effects. It should hence not be interpreted as a direct indicator for agricultural or hydrological (streamflow) drought (Mueller and Seneviratne, 2012; Orlowsky and Seneviratne, 2012). Furthermore, CDD is a metric for short dry spells, which represent only a snapshot of the overall changes in dryness (IPCC, 2012), while high-impact drought events like the Big Dry in Australia (Kiem and Verdon-Kidd, 2010) or the recent California drought stretch over months and potentially years (Ault et al., 2014). Nevertheless, CDD as well as RX5day can be seen as proxies for the precipitation-related component when assess- ing drought and flooding risks, respectively, and the results and impacted regions identified here are broadly consistent with projections based on more comprehensive indicators for droughts (Dai, 2012; Prudhomme et al., 2013) and flooding risk (Hirabayashi et al., 2013) alike.

\section{Water availability}

Already today, water scarcity is among the biggest challenges for ecosystems and human societies in many regions globally. To assess changes in water availability (assessed here as the annual mean surface and subsurface runoff - QTOT) at $1.5^{\circ} \mathrm{C}$ and $2{ }^{\circ} \mathrm{C}$, we follow the approach outlined above in Sect. 2. Projections are based on 11 global hydrological models (GHM) that participated in the ISI-MIP intercomparison (Schewe et al., 2014). These are forced with bias-corrected climate simulations from five CMIP5 GCMs (HadGEM2-ES, IPSL-CM5A-LR, MIROC-ESM-CHEM, GFDL-ESM2M, and NorESM1-M, see Hempel et al. (2013) for further details on the biascorrection methodology applied). This GCM ensemble has been shown to reproduce regional seasonal precipitation and temperature reasonably well (McSweeney and Jones, 2016), which is further improved by applying a bias correction (Hempel et al., 2013). However, the bias correction method is not designed to retain a physical consistent representation of extreme weather events (Sippel et al., 2015), and thereby 


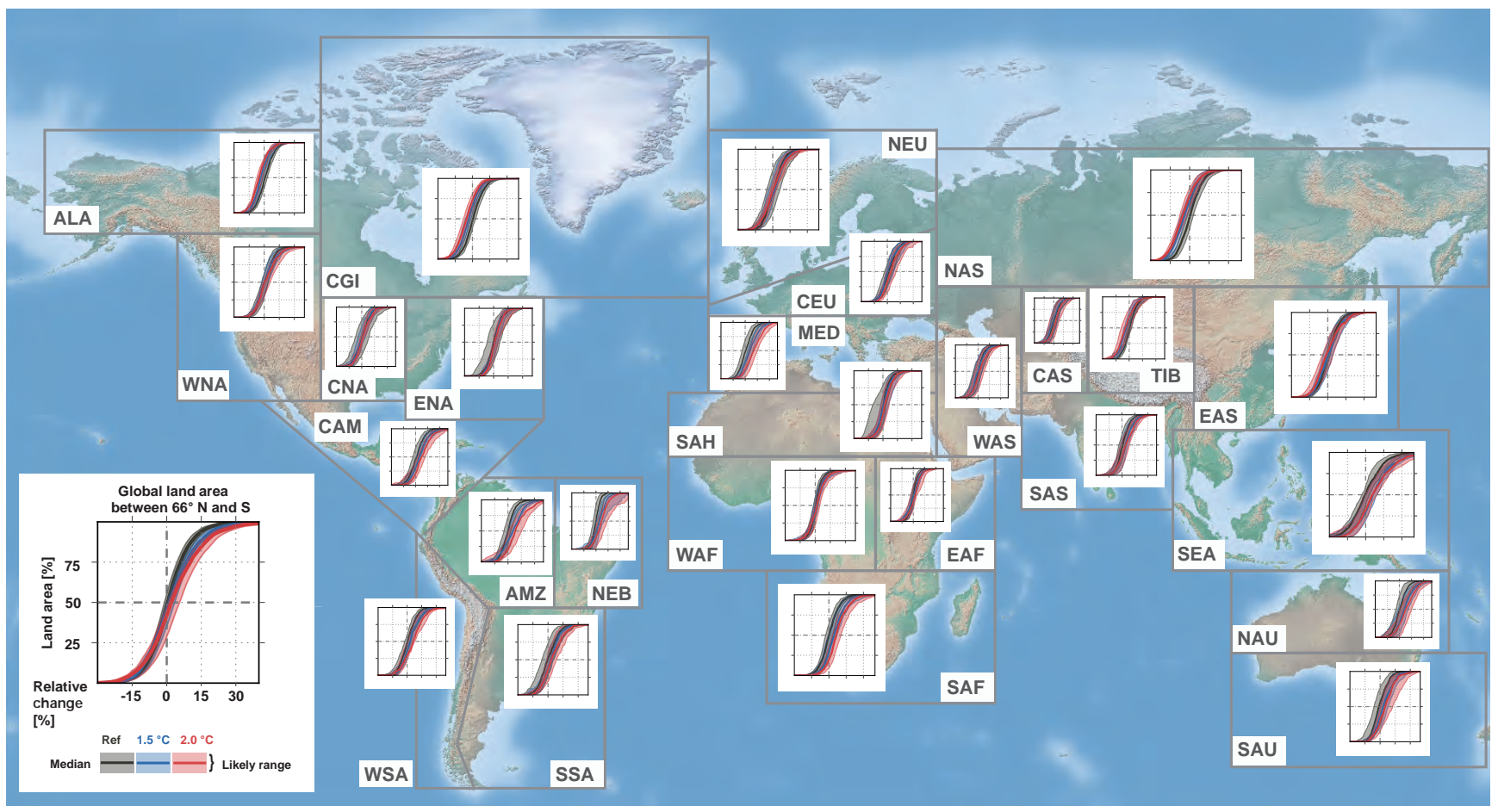

Figure 6. Same as Fig. 2 but for CDD. Changes are given relative to the 1986-2005 reference period.

the intercomparibility with the quantitative results reported in Sect. 3 is limited.

Each of the GCM-GHM combinations is treated as an individual ensemble member resulting in a $N=55$ ensemble as a basis for the KS tests described above. Unlike the CMIP5 ensemble, only one realization of each experiment is available and as a consequence the effect of natural variability cannot be assessed. ISI-MIP impacts are assessed at a $0.5^{\circ}$ by $0.5^{\circ}$ resolution.

For a warming of $2{ }^{\circ} \mathrm{C}$, reductions in water availability of up to $30 \%$ are projected in several - mainly subtropical - regions, in particular affecting the Mediterranean, South Africa, Central and southern South America and South Australia (Fig. 7). A relative increase in runoff is projected in much of the high northern latitudes, as well as in parts of India, East Africa and parts of the Sahel. While many of these findings are consistent with earlier studies (James and Washington, 2013; Schewe et al., 2014), some may depend on the five GCMs chosen here and may be less robust in larger CMIP5 GCM ensembles (Knutti and Sedláček, 2012).

Figure 7 (lower panel) and Fig. 8 illustrate the difference between a $1.5^{\circ} \mathrm{C}$ and $2{ }^{\circ} \mathrm{C}$ warming. Differences are most prominent in the Mediterranean region where the median reduction in runoff almost doubles from about $9 \%$ (likely range: $4.5-15.5 \%)$ at $1.5{ }^{\circ} \mathrm{C}$ to $17 \%(8-28 \%)$ at $2{ }^{\circ} \mathrm{C}$. For several other world regions such as Central America and Australia, there is an increasing risk of substantial runoff reductions exceeding $30 \%$ for the upper limit of the $66 \%$ quantile, although projections are highly uncertain (Table $\mathrm{S} 4$ and Fig. 8). The differences between $1.5^{\circ} \mathrm{C}$ and $2{ }^{\circ} \mathrm{C}$ are smaller for many other regions, but the KS-test reveals that they are statistically significant for all world regions assessed (Table S4). These runoff results are also consistent with the findings on precipitation-related extremes presented in Sect. 3.3.

In addition to changes in fresh water availability as a consequence of changes in the hydrological cycle, saltwater intrusion resulting from rising sea levels or extreme coastal flooding has to be considered (Werner et al. , 2013). Although strongly dependent on local circumstances including regional water management and coastal protection, saltwater intrusion might present a substantial challenge in particular for lowlying coastal areas and small island states (Jiménez Cisneros et al., 2014).

\section{Crop yields}

\subsection{Methods and data}

We assess future agricultural crop yields in a 1.5 and $2{ }^{\circ} \mathrm{C}$ warmer world for the four major staple crops - maize, wheat, rice and soy based on projections from the ISI-MIP Fast Track database (Warszawski et al., 2014; Rosenzweig et al., 2014). Projections for agricultural production depend on a complex interplay of a range of factors, including physical responses to soils, climate and chemical processes, or nutrient and water availability, but are also strongly deter- 


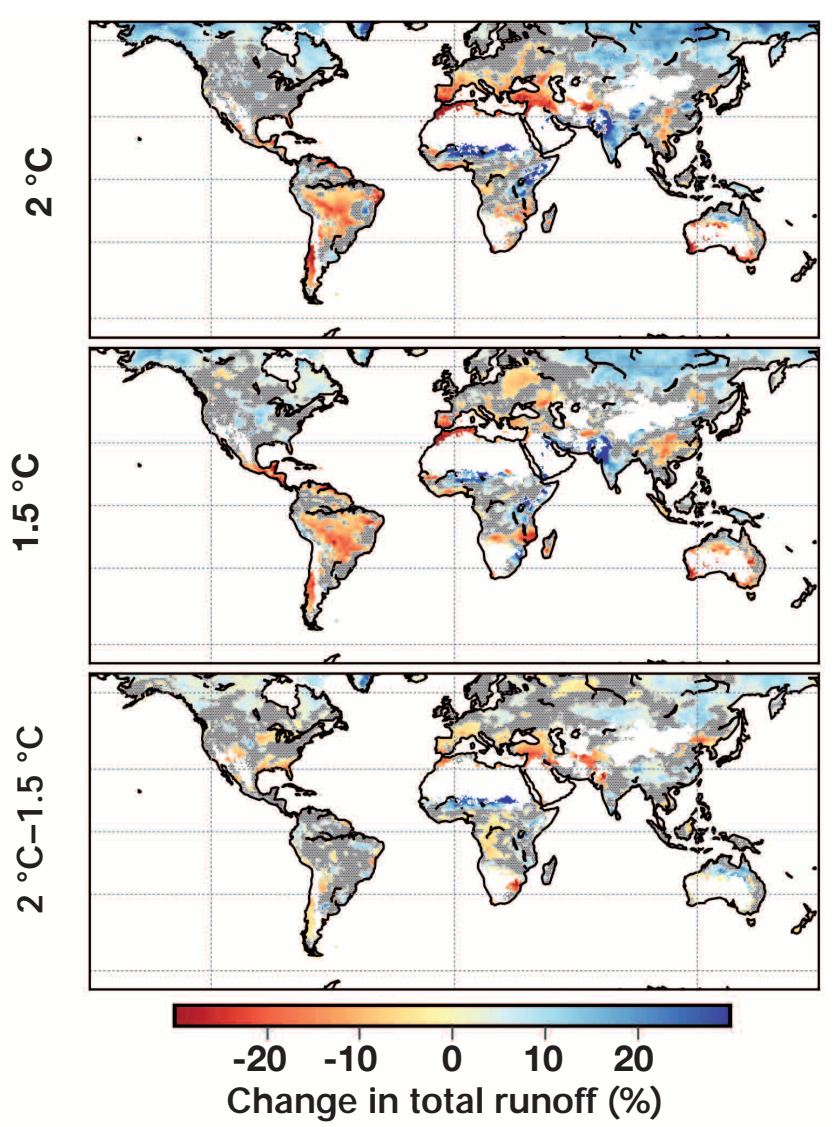

Figure 7. Median projections for changes in annual mean runoff for a warming of $2^{\circ} \mathrm{C}$ (upper panel), $1.5^{\circ} \mathrm{C}$ (middle panel) and the difference between both levels (lower panel) relative to the 1986-2005 reference period. The projections are based on the ISI-MIP GCMGHM model ensemble. Grid cells where less than $66 \%$ of all GCMGHM pairs agree with the median sign of change are hatched out. Grid cells with an annual mean runoff of less than $0.05 \mathrm{~mm}_{\text {day }}{ }^{-1}$ are masked white.

mined by human development and management. The representation of these processes differs strongly between different agricultural models. While studies suggest an increase in productivity for some crops as a result of higher $\mathrm{CO}_{2}$ concentrations, large uncertainties remain with regard to temperature sensitivity, nutrient and water limitations, differences in regional responses and also the interactions between these different factors (Rosenzweig et al., 2014). According to their metabolic pathways of carbon fixation in photosynthesis, main crops can be categorized as $\mathrm{C} 3$ and $\mathrm{C} 4$ plants. $\mathrm{C} 4$ plants such as maize, sorghum and sugar cane have a high $\mathrm{CO}_{2}$ efficiency and as a consequence profit little from increased $\mathrm{CO}_{2}$ concentrations, whereas for $\mathrm{C} 3$ plants including wheat, rice and soy a positive $\mathrm{CO}_{2}$-fertilization effect is to be expected. At the same time, increased $\mathrm{CO}_{2}$ concentrations may lead to improved water use efficiency (Eamus, 1991). However, the effect of elevated $\mathrm{CO}_{2}$ concentrations on plant growth is highly uncertain (McGrath and Lobell, 2013) and the representation of this effect greatly differs between different agricultural models. As a consequence, the ISI-MIP protocol has been conducted with and without accounting for $\mathrm{CO}_{2}$-fertilization effects (further referred to as the $\mathrm{CO}_{2}$ ensemble and noCO $\mathrm{C}_{2}$-ensemble, respectively). Recent findings also underline the importance of elevated temperatures and heat extremes (Gourdji et al., 2013; Deryng et al., 2014), ozone concentrations (Tai et al., 2014) as well as the potential of increasing susceptibility to disease as a consequence of elevated $\mathrm{CO}_{2}$ levels (Vaughan et al., 2014) for agricultural yields, which may counteract potential yield gains by $\mathrm{CO}_{2}$-fertilization (Porter et al., 2014). Results for the $\mathrm{CO}_{2}$ and noCO $\mathrm{C}_{2}$-ensembles are presented separately, showing the range of potential manifestations and the additional risks of regional yield reductions, if effects of $\mathrm{CO}_{2}$-fertilization turn out to be lower than estimated by the model ensemble.

The ISI-MIP ensemble contains simulations based on seven Global Gridded Crop Models (GGCM) for wheat, maize and soy and six GGCM for rice, run with input from five CMIP5 GCMs (for further information see Rosenzweig et al., 2014). For the $\mathrm{CO}_{2}$-ensemble, all model combinations are available (35, and 30 for rice), while for the noCO 2 -ensemble runs have been provided for 23 (18 for rice) GGCM-GCM combinations. We restrict future crop growing areas to present-day agricultural areas (based on Monfreda et al., 2008) and assume no change in management type, meaning that "rainfed" and "irrigation" conditions are kept constant as well.

As in previous sections, the results presented here are based on 20-year time slices from the RCP8.5 simulations and changes are given relative to the 1986-2005 reference period. The choice of displaying relative changes comes with several advantages, but will also lead to a disproportional visual amplification of minor absolute changes for regions with small present-day yields, in particular in the high northern latitudes. An overview of the regionally resolved present-day share in global production is given in Fig. S5.

Since agricultural impacts depend both on climatological changes and changes in the atmospheric $\mathrm{CO}_{2}$ concentrations, the assumption of time-independent impacts underlying the time-slice approach as discussed above does not fully hold for agricultural projections accounting for the effects of $\mathrm{CO}_{2}$ fertilization (the $\mathrm{CO}_{2}$-ensemble) and will lead to increased inner-ensemble spread as a consequence. Please note that the regional aggregation for agricultural yields is not based on absolute yield change but on land area, as for the other indicators studied above. Since societal impacts of changes in agricultural production go beyond mere changes in yield, but also include for example local livelihood dependencies (Schellnhuber et al., 2013; Olsson et al., 2014), our assessment of local yield changes (on a grid-cell level) supplements and extends previous yield-centered analysis (Rosenzweig et al., 2014). Maps for the projected differences of yield changes on a grid-cell basis are provided in the Supplement. 


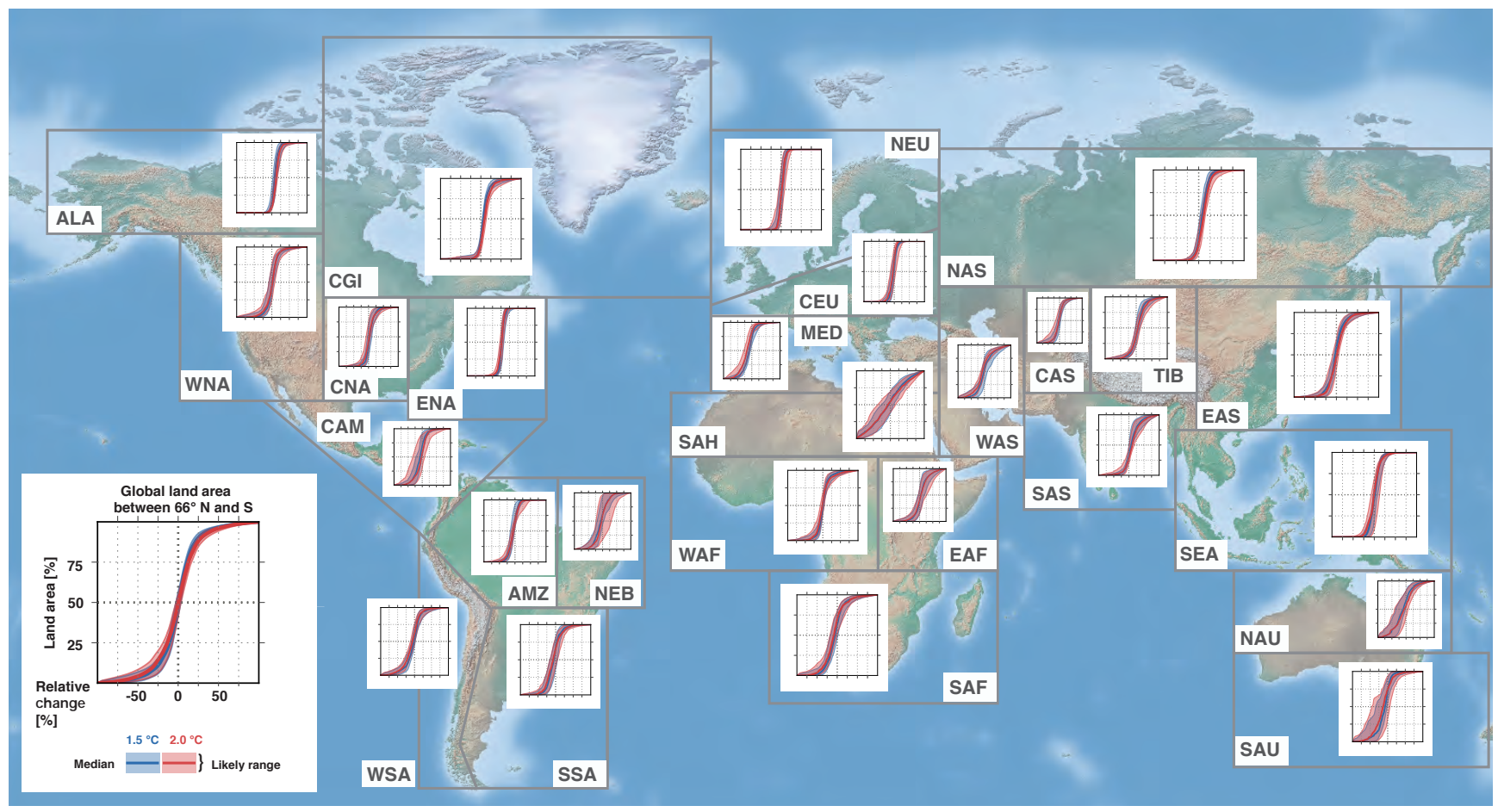

Figure 8. Same as Fig. 2 but for total annual runoff. Changes are given relative to the 1986-2005 reference period.

\subsection{Results}

\subsubsection{Wheat}

Our analysis reveals very small local median yield changes for $50 \%$ of the global land area for a $1.5^{\circ} \mathrm{C}$ and $2{ }^{\circ} \mathrm{C}$ warming. However, the uncertainties of these projections are substantial and reductions of about 6 and $8 \%$ for $1.5^{\circ} \mathrm{C}$ and $2{ }^{\circ} \mathrm{C}$, respectively, mark the lower end of the likely range (compare Table S5). For the noCO $\mathrm{CO}_{2}$-ensemble, we find substantial median reductions in local wheat yields of $14 \%$ at $1.5^{\circ} \mathrm{C}$, with a statistically significant higher decrease of $19 \%$ at $2{ }^{\circ} \mathrm{C}$ and potential reductions of up to $20 \%\left(1.5^{\circ} \mathrm{C}\right)$ and $37 \%\left(2{ }^{\circ} \mathrm{C}\right)$ as lower limits for the likely range. The results of the KS-tests based on individual model combinations are given in Table S5 and for the global level as well as most regions, more than $83 \%(90 \%)$ of all ensemble members indicate a robust difference between projected impacts at $1.5^{\circ} \mathrm{C}$ and $2{ }^{\circ} \mathrm{C}$ for the $\mathrm{CO}_{2}($ noCO 2$)$-ensemble.

Best estimate local yield reductions are projected for the tropical region of about $9 \%(15 \%)$ for $1.5^{\circ} \mathrm{C}\left(2{ }^{\circ} \mathrm{C}\right)$ that are particularly pronounced in West African - median reduction of $13 \%(19 \%)$. Under a $1.5^{\circ} \mathrm{C}\left(2^{\circ} \mathrm{C}\right)$ warming, reductions of up to $25 \%$ (42\%) are within the likely range of the $\mathrm{CO}_{2}$ ensemble projections and for the noCO $\mathrm{C}_{2}$-ensembles, median reductions of $28 \%$ (35\%) would be projected.

\subsubsection{Maize}

The effects of elevated $\mathrm{CO}_{2}$ concentrations affect maize yields to a much lesser extent, as conditions are mostly saturated at present levels (see e.g. Leakey et al., 2006). Differences between runs are thus less pronounced for maize yields, where yield reductions are projected for both the $\mathrm{CO}_{2}$ and the noCO $\mathrm{C}_{2}$-ensemble. As the number of runs differ between the two ensembles (see Methods), the small differences are likely due to the different ensemble size. Thus, we only discuss results for the $\mathrm{CO}_{2}$-ensemble here. Differences between the warming levels are significant (all ensemble members indicate a significant difference for the global crop area, see Table S6), with median local yield reductions experienced by $50 \%$ of the global crop area of around 1.5 and $6 \%$ for $1.5^{\circ} \mathrm{C}$ and $2{ }^{\circ} \mathrm{C}$ warming, respectively. Risks of reductions of up to $26 \%$ at $1.5^{\circ} \mathrm{C}$ and $38 \%$ at $2{ }^{\circ} \mathrm{C}$ are within the likely range globally (compare Fig. 9 and Table S6).

As apparent in Fig. 9, the likely range is deferred towards stronger reductions. Similar regional patterns compared to wheat projections are apparent. Again, the highest relative median changes occur in regions with a relatively low share of global production. For central North America, where at present about $10 \%$ of global maize is produced, substantial differences between the two warming levels are projected, and risks for a strong negative effect in this region more than double between $1.5^{\circ} \mathrm{C}$ and $2{ }^{\circ} \mathrm{C}$ warming from 15.5 to $37 \%$ (upper limit of the $66 \%$ range). Tropical regions such as Central America, the Amazon and South-East Asia are projected 


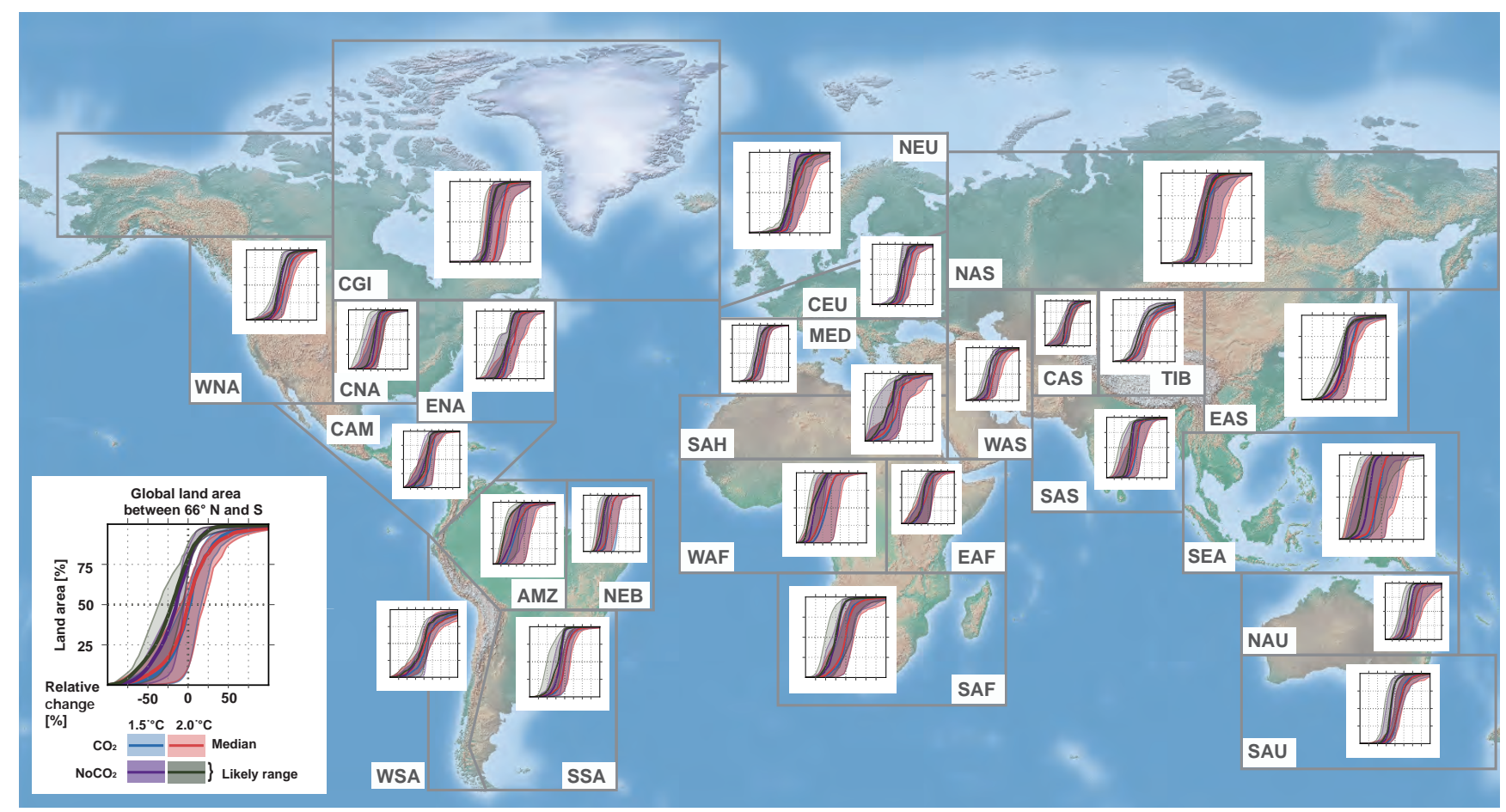

Figure 9. Same as Fig. 2 but for changes in wheat yields. Changes are given relative to the 1986-2005 reference period and ensemble projections excluding the effect of $\mathrm{CO}_{2}$-fertilization are shown separately. The CDFs are derived only over the present-day growing areas of the crop.

to experience median local yield reductions exceeding $5 \%$ for $1.5^{\circ} \mathrm{C}$ and up to and more than $10 \%$ for $2{ }^{\circ} \mathrm{C}$, while projections for the full tropical region do not differ substantially from the global projections.

\subsubsection{Soy}

Projections of changes in soy yields between the two assessed warming levels show robust differences (see Table S7). For the $\mathrm{CO}_{2}$-ensemble, a median increase in global yields of $7 \%$ is projected for $50 \%$ of the global area under a warming of $1.5^{\circ} \mathrm{C}$. This median increase vanishes for $2^{\circ} \mathrm{C}$. Global differences between warming levels for the noCO ${ }_{2}$ ensemble are smaller but nonetheless robust, with median reductions of 10 and $12 \%$, respectively.

Regionally, the differences for the noCO ${ }_{2}$-ensemble are more pronounced, especially in those regions with a large share in present-day global soy production. Median yields for the Amazon (AMZ) region, currently producing about $7 \%$ of global soy (Monfreda et al., 2008, see also Fig. S5), are projected to reduce from $15 \%$ under $1.5^{\circ} \mathrm{C}$ to $20 \%$ under $2{ }^{\circ} \mathrm{C}$ warming. Similar robust differences in yield reductions between $1.5^{\circ} \mathrm{C}$ and $2{ }^{\circ} \mathrm{C}$ warming are also projected for the major soy producers in central North America and south-east South America. For North Asia, where currently over $7 \%$ of soy production takes place, median increases in yields of 28 and $24 \%$ are projected for a warming of $1.5^{\circ} \mathrm{C}$ for the noCO $\mathrm{C}_{2}$ and $\mathrm{CO}_{2}$ ensembles, respectively. However, uncertainties for this region are high and a risk of substantial reductions of $25 \%\left(1.5^{\circ} \mathrm{C}\right)$ and $20 \%\left(2{ }^{\circ} \mathrm{C}\right)$ in the $\mathrm{CO}_{2}$ ensemble are within the likely range of the ensemble projections.

\subsubsection{Rice}

Median changes in global rice yields for the $\mathrm{CO}_{2}$-ensemble do not differ between the assessed warming levels, with projected increases of about $7 \%$ although the respective local yield change distributions are significantly different (compare Table S8). The distribution of possible developments indicates risk of substantial reductions of up to 17 and $14 \%$ at $1.5^{\circ} \mathrm{C}$ and $2{ }^{\circ} \mathrm{C}$. For the noCO $\mathrm{CO}_{2}$-ensemble, reductions of 8 and $15 \%$ are projected for the two warming levels.

The effects of $\mathrm{CO}_{2}$-fertilization consistently indicates yield increases across regions for median projections. While differences between warming levels are apparent for some regions and the $\mathrm{CO}_{2}$-ensemble, global estimates are very similar between both warming levels. For the noCO ${ }_{2}$-ensemble, robust differences between $1.5^{\circ} \mathrm{C}$ and $2{ }^{\circ} \mathrm{C}$ warming are apparent for all major rice producing regions, including all Asian regions where a total of $40 \%$ of rice is produced today (EAS, SAS, SEA, TIB) as well as the Amazon, and South American rice producers. Reductions are projected to double between the two warming levels, for example in South Asia, 


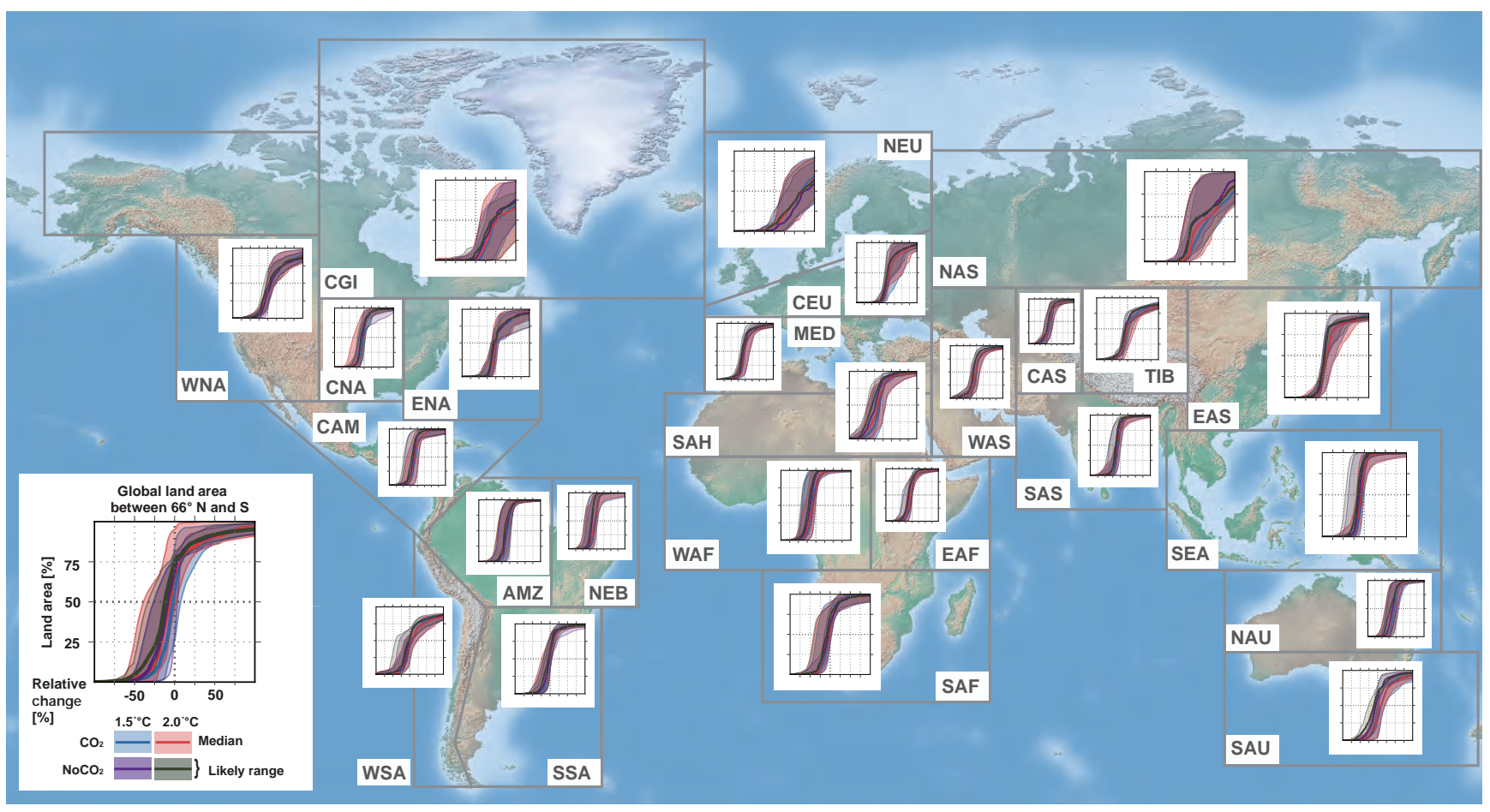

Figure 10. Same as Fig. 9, but for changes in maize yields.

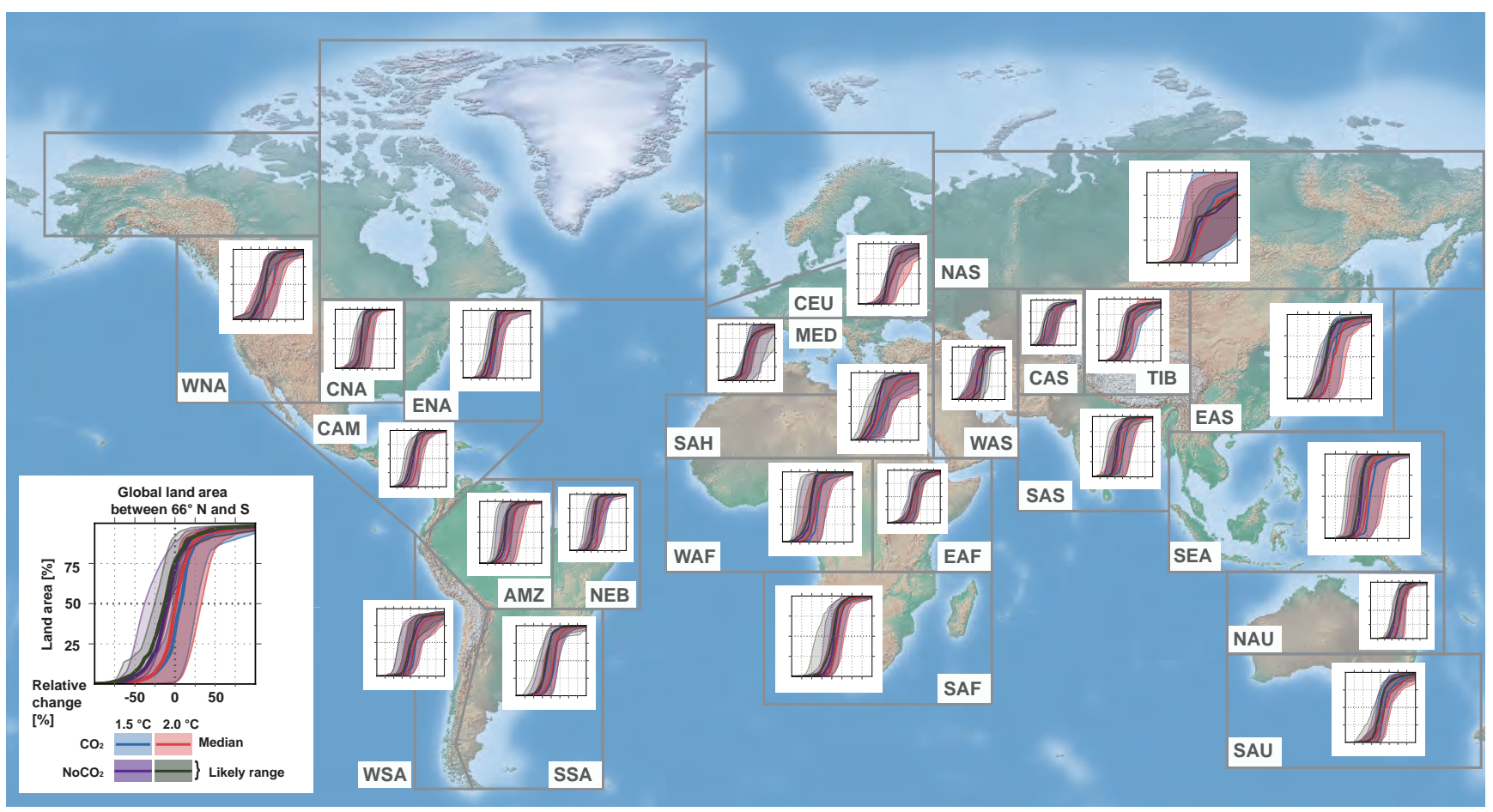

Figure 11. Same as Fig. 9, but for changes in soy yields. 
south-east South America and the Tibetan Plateau. For these regions, median projections are close to the lower end of the likely range (compare Fig. 12 and Table S8).

\subsection{Discussion of crop yield projections}

Our projections of local agricultural yields reveal substantial uncertainties in global median regional yield changes (Figs. 9 to 12$)$ with a likely range (66\% - likelihood) comprising zero. For wheat, rice and soy, our projections indicate differences between the $\mathrm{CO}_{2}$ and noCO $\mathrm{CO}_{2}$ assessments, which are generally much larger than those between a $1.5^{\circ} \mathrm{C}$ and $2^{\circ} \mathrm{C}$ warming. While substantial uncertainty renders a differentiation between impacts at $1.5^{\circ} \mathrm{C}$ and $2{ }^{\circ} \mathrm{C}$ warming difficult in most world regions, a clear signal emerges for the noCO $\mathrm{CO}_{2}$-ensemble, that may serve as a high-risk illustration of potential climate impacts on agricultural production. In the noCO ${ }_{2}$-ensemble, local yields are projected to decrease between $1.5^{\circ} \mathrm{C}$ and $2{ }^{\circ} \mathrm{C}$ for all crop types.

As discussed above, our crop-yield projections are subject to a range of uncertainties also related to extreme weather events. Uncertainties in both the bias-corrected climate model input (Sippel et al., 2015) as well as the impact model representation of such events (Deryng et al., 2014; Asseng et al., 2014; Lobell et al., 2012) limit the confidence in the projections of the effect of extreme weather events on crop yields. Observational evidence, however, indicates substantial impacts of specifically drought and extreme heat events on crop yields (Lesk et al., 2016). Given the pronounced increase in extreme heat events under global warming in general and also specifically between $1.5^{\circ} \mathrm{C}$ and $2{ }^{\circ} \mathrm{C}$ (compare Figs. 2 and 3, our estimates of the absolute change in local crop yields as well as the difference between $1.5^{\circ} \mathrm{C}$ and $2{ }^{\circ} \mathrm{C}$ should be seen as a conservative estimate.

Our results indicate that risks are region and crop specific and are in line with findings of previous model intercomparison studies (Asseng et al., 2014; Rosenzweig et al., 2014). While high-latitude regions may benefit, median projections for local yields in large parts of the tropical land area are found to be negatively affected already at $1.5^{\circ} \mathrm{C}$. Risks increase substantially, if effects of $\mathrm{CO}_{2}$-fertilization are less substantial or counter-acted by other factors such as extreme temperature response, land degradation or nitrogen limitation (Rosenzweig et al., 2014; Bodirsky and Müller, 2014; Bodirsky et al., 2014). In a statistical analysis of climate impacts on wheat and barley yields in Europe, Moore and Lobell (2015) report an overall negative contribution of climatic factors in line with findings of a meta-analysis by Asseng et al. (2014), which questions the positive effects projected in our $\mathrm{CO}_{2}$-ensemble for this region and further support our approach of singling out noCO $\mathrm{CO}_{2}$-ensemble projections. Given that a $1.5^{\circ} \mathrm{C}$ warming might be reached already around 2030, our findings underscore the risks of global crop yield reductions due to climate impacts outlined by Lobell and Tebaldi (2014), while giving further indications for the regional di- versity of climate impacts with tropical regions being a hotspot for climate impacts on local agricultural yields (Müller et al., 2014).

\section{Sea-level rise}

\subsection{Methods}

Projections for sea-level rise (SLR) cannot be based on a time-slice approach because of the importance of the timelagged response of the ocean and cryosphere to the warming signal. Therefore, we selected two multi-gas scenarios illustrative of a $1.5^{\circ} \mathrm{C}$ and $2{ }^{\circ} \mathrm{C}$ warming to assess SLR impacts over the entire 21 st century from a large emission scenario ensemble created by Rogelj et al. (2013). These scenarios were created with the integrated assessment modelling framework MESSAGE (the Model for Energy Supply Strategy Alternatives and their General Environmental Impact, Riahi et al., 2007). For both scenarios, temperature projections are derived with the reduced complexity carbon cycle and climate model MAGICC (Meinshausen et al., 2011) in a probabilistic setup (Meinshausen et al., 2009), which has been calibrated to be in line with the uncertainty assessment of equilibrium climate sensitivity of the IPCC AR5 (Rogelj et al., 2012, 2014). Each probabilistic setup ensemble consists of 600 individual scenario runs. The first scenario keeps GMT to below $2{ }^{\circ} \mathrm{C}$ relative to pre-industrial levels (18501875 ) during the 21 st century with $50 \%$ probability. The second scenario reduces emissions sooner and deeper, and keeps warming to below $1.5^{\circ} \mathrm{C}$ relative to pre-industrial levels during the 21 st century with about $50 \%$ probability and returns end-of-century warming to below $1.5^{\circ} \mathrm{C}$ with about $70 \%$ probability. See Fig. 13 (upper panel) for median temperature projections for the 2 and $1.5^{\circ} \mathrm{C}$ scenario and their associated uncertainty bands. Since the projections for coral reef degradation include a time-dependent adaptation scenario, the same approach is taken for the coral reef projections (see Sect. 7).

SLR projections are based on Perrette et al. (2013), who developed a scaling approach for the various SLR contributions according to an appropriately chosen climate predictor - in this case GMT increase and ocean heat uptake. Coupled with output from the MAGICC model, this allows us to emulate the sea-level response of GCMs to any kind of emission scenario within the calibration range of the method that is spanned by the RCPs.

Consistent with the relationship found in CMIP3 and CMIP5 GCMs, ocean thermal expansion is assumed to be proportional to cumulative ocean heat uptake (Church et al., 2013). Mountain glacier melt is computed following a widely used semi-empirical relationship between rate of glacier melt, remaining surface glacier area, and temperature anomaly with respect to pre-industrial levels. This approach assumes constant scaling between area and volume (Wigley and Raper, 2005; Meehl et al., 2007), with parameters cho- 


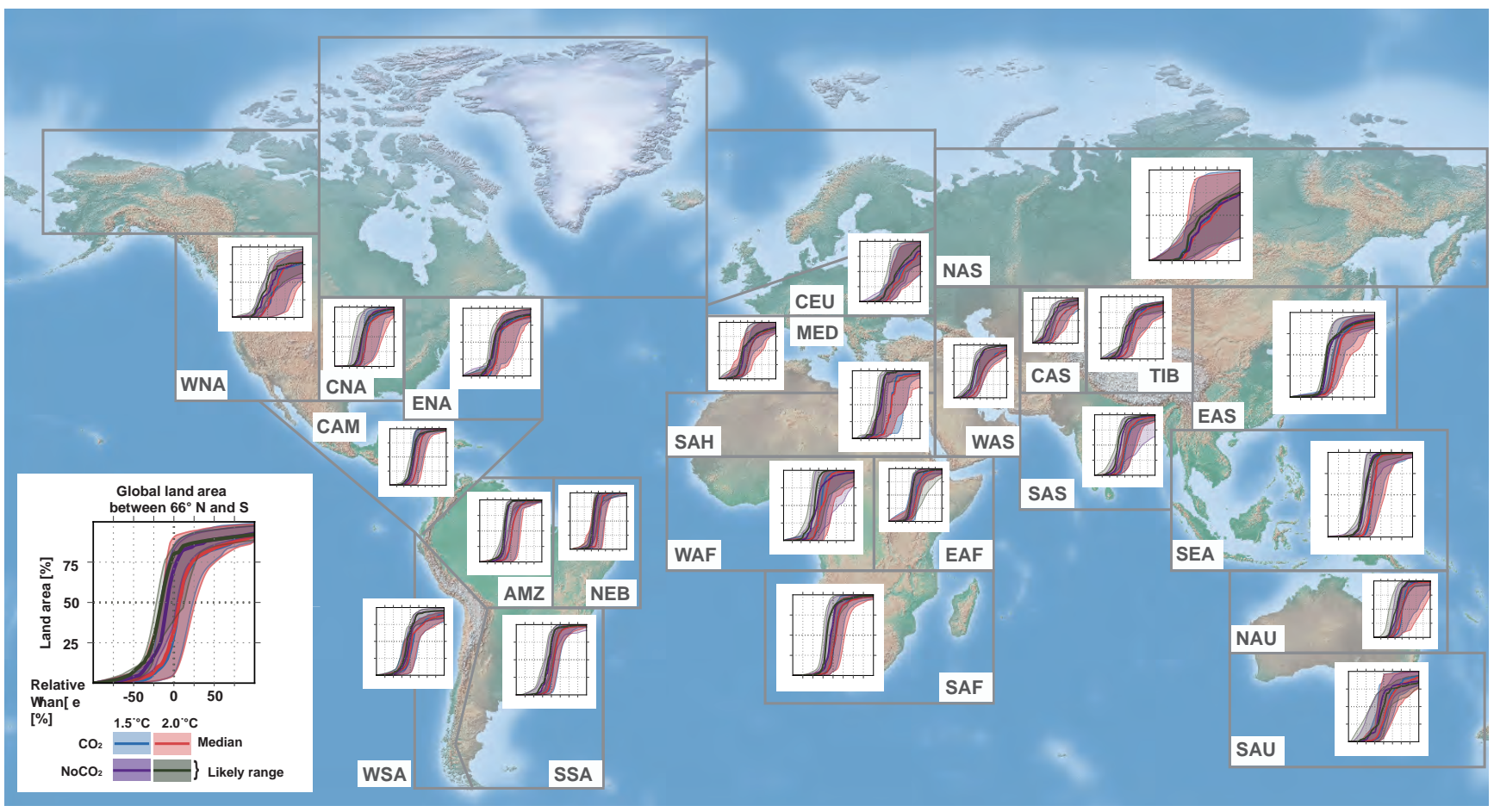

Figure 12. Same as Fig. 9 but for changes in rice yields.
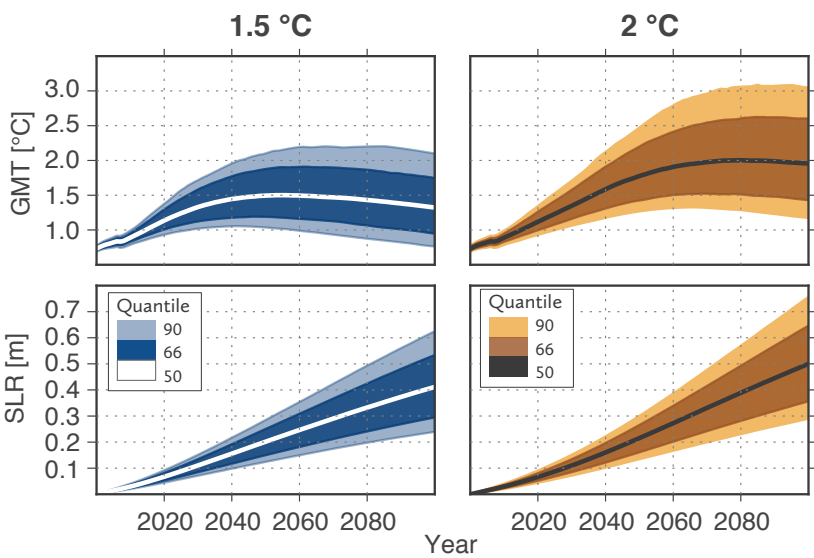

Figure 13. Upper panel: probabilistic GMT projections for illustrative emission scenarios with a peak warming of $1.5^{\circ} \mathrm{C}$ (left panels) and $2{ }^{\circ} \mathrm{C}$ (right panels) above pre-industrial levels during the 21 st century. Lower panels: probabilistic projections of global sealevel rise (SLR) for both scenarios relative to 1986-2005 levels. Uncertainty bands indicate the likely range (66\% probability within this range) and the very likely range (90\% probability), respectively.

sen to account for current melt rate and known glacier volume (Eq. 1 and Table 2 in Perrette et al., 2013). As already noticed by Gregory and Huybrechts (2006) (their Fig. 5), the surface mass balance (SMB) anomaly from the Greenland ice sheet can be approximated with reasonable accu-
Table 2. Projections for sea-level rise above year 2000 levels for two illustrative $1.5^{\circ} \mathrm{C}$ and $2{ }^{\circ} \mathrm{C}$ scenarios (see Fig. 13). Square brackets give the likely ( $66 \%$ ) range.

\begin{tabular}{|c|c|c|}
\hline & $1.5^{\circ} \mathrm{C}$ & $2{ }^{\circ} \mathrm{C}$ \\
\hline SLR 2081-2100 [m] & $0.37[0.27,0.48]$ & $0.44[0.32,0.57]$ \\
\hline SLR $2100[\mathrm{~m}]$ & $0.41[0.29,0.53]$ & $0.5[0.36,0.65]$ \\
\hline Rate of SLR 2041-2060 [mm yr $\left.{ }^{-1}\right]$ & $4.6[3.2,5.8]$ & $5.6[4.0,7.0]$ \\
\hline Rate of SLR $2081-2100\left[\mathrm{~mm} \mathrm{yr}^{-1}\right]$ & $4.0[2.7,5.5]$ & $5.6[3.8,7.7]$ \\
\hline
\end{tabular}

racy as a quadratic fit to global mean temperature anomaly. Here we adopted the same functional form, but calibrated it to more recent projections by Fettweis et al. (2013). Following Hinkel et al. (2014), we scaled up these projections by $20 \% \pm 20 \%$ to account for missing dynamic processes (elevation feedback $10 \% \pm 5 \%$, changes in ice dynamics $10 \% \pm 5 \%$, and $\pm 10 \%$ arising from the skill of the SMB model to simulate the current SMB rate over Greenland). The climate-independent land-water contribution has been added for all scenarios following Wada et al. (2012).

Beyond the scaling approach, the main advancement of our approach compared to the IPCC AR5 (Church et al., 2013) stems from the inclusion of scenario-dependent Antarctic ice-sheet projections following Levermann et al. (2014). Linear response functions were derived from idealized step-forcing experiments from the SeaRISE project (Bindschadler et al., 2013) as a functional link between the rate of ice shelf melting and dynamical contribution to 
SLR over four Antarctic sectors and various ice-sheet models. Levermann et al. (2014) further assume linear scaling between global surface air warming, local ocean warming, and ice-shelf melting in each of the sectors. They adopted a Monte Carlo approach with 50000 samples to combine the various parameter ranges, GCMs and ice-sheet models. To our knowledge, this is the most comprehensive attempt to date to link climate warming and Antarctic ice-sheet contributions to scenario-dependent sea-level rise over the 21 st century.

\subsection{Results}

For an illustrative $2{ }^{\circ} \mathrm{C}$ scenario, we project a median SLR of about $50 \mathrm{~cm}(36-65 \mathrm{~cm}$, likely range) by 2100 and a rate of rise of 5.6 (4-7) $\mathrm{mm} \mathrm{yr}^{-1}$ over the 2081-2100 period. Under our illustrative $1.5^{\circ} \mathrm{C}$ scenario, projected SLR in 2100 is about $20 \%$ (or $10 \mathrm{~cm}$ ) lower, compared to the $2{ }^{\circ} \mathrm{C}$ scenario (see Table 2). The corresponding reduction in the expected rate of SLR over the 2081-2100 period is about $30 \%$. More importantly, and in contrast to the projections for the $2{ }^{\circ} \mathrm{C}$ scenario, the rate for the $1.5^{\circ} \mathrm{C}$ scenario is projected to decline between mid-century and the 2081-2100 period by about $0.5 \mathrm{~mm} \mathrm{yr}^{-1}$, which substantially reduces the multicentennial SLR commitment (Schaeffer et al., 2012).

The projected difference in SLR between the $1.5^{\circ} \mathrm{C}$ and $2{ }^{\circ} \mathrm{C}$ scenarios studied here is comparable to the difference between the RCP2.6 and RCP4.5 scenarios (Hinkel et al., 2014; Church et al., 2013), while the projected median GMT difference between the two RCP scenarios is about $0.8^{\circ} \mathrm{C}$ for the 2081-2100 period. The relatively higher sensitivity of SLR in the 21st century to temperature increase at low climate warming is probably related to the earlier peaking of GMT under such scenarios and thus an already longer adjustment period for the time-lagged ocean and cryosphere. This leads to a larger share of committed multi-centennial SLR to occur in the 21 st century. On multi-centennial timescales these scenario-dependent differences are expected to vanish. A long-term difference, however, may arise from contributions by mountain glacier melt, which are particularly vulnerable to GMT increase and thus differences in melted mountain glacier volume are higher for lower emission scenarios.

While SLR projections for the two illustrative 1.5 and $2{ }^{\circ} \mathrm{C}$ differ substantially, this effect is strongly scenario dependent. In particular, most emission pathways labelled as $1.5^{\circ} \mathrm{C}$ scenarios allow for a temporal overshoot in GMT and a decline below $1.5^{\circ} \mathrm{C}$ with a $50 \%$ probability by 2100 (Rogelj et al., 2015), whereas the illustrative $1.5^{\circ} \mathrm{C}$ scenario used here does not allow for a GMT overshoot, but stays below $1.5^{\circ} \mathrm{C}$ over the course of the 21 st century. For time-lagged climate impacts such as SLR that depend on the cumulative heat entry in the system, the difference between a scenario allowing for a GMT overshoot and one that does not will be significant.

Sea-level adjustment to climate warming has a timescale much larger than a century as a result of slow ice-sheet pro- cesses and ocean heat uptake. This means that in all emission scenarios considered, sea level will continue to rise beyond 2100. Levermann et al. (2013) have shown that on a 2000-year timescale, sea-level sensitivity to global mean temperature increase is about $2.3 \mathrm{~m}$ per ${ }^{\circ} \mathrm{C}$. In addition to that, Levermann et al. (2013) report a steep increase in longterm SLR between $1.5^{\circ} \mathrm{C}$ and $2^{\circ} \mathrm{C}$ as a result of an increasing risk of crossing a destabilizing threshold for the Greenland ice-sheet (Robinson et al., 2012). The disintegration process that would lead to 5-7 $\mathrm{m}$ global SLR, however, is projected to happen on the timescale of several millennia.

Recent observational and modelling evidence indicates that a marine ice sheet instability in the West Antarctic may have already been triggered, which could lead to an additional SLR commitment of about $1 \mathrm{~m}$ on a multi-centennial timescale. Spill-over effects of this destabilization on other drainage basins and their relation to GMT increase are as yet little understood (Rignot et al., 2014; Joughin et al., 2014; Favier et al., 2014), and there are indications that a destabilization of the full West Antarctic ice-sheet could eventually be triggered (Feldmann and Levermann , 2015). Similarly, Mengel and Levermann (2014) report a potential marine icesheet instability for the Wilkens Basin in West Antarctica containing 3-4 m of global SLR. The dynamics of these coupled cryosphere-oceanic systems remain a topic of intense research. Current fine-scale ocean models, suggest increased intrusion of warm deep water on the continental shelf as a result of anthropogenic climate change and thus indicate an increasing risk with increasing warming (Hellmer et al., 2012; Timmermann and Hellmer, 2013). Given the risk of potentially triggering multi-metre SLR on centennial to millennial timescales, this clearly calls for a precautionary approach that is further underscored by evidence from paleo-records, which reveals that past sea-levels might have about $6-9 \mathrm{~m}$ above present day for levels for a GMT increase not exceeding $2{ }^{\circ} \mathrm{C}$ above pre-industrial levels (Dutton et al., 2015).

\section{Coral reef systems}

\subsection{Methods}

The projections of the degradation of coral reef sites uses the coral bleaching model developed in Frieler et al. (2012) based on the two illustrative $1.5^{\circ} \mathrm{C}$ and $2{ }^{\circ} \mathrm{C}$ global emission pathways introduced in Sect. 6.1. The framework applies a threshold-based bleaching algorithm by Donner (2009), which is based on degree heating months (DHMs), to sea surface temperature (SST) pathways of 2160 individual geospatial locations of coral reef sites (see http://www.reefbase.org) and generates as output the fraction of coral reef locations subject to long-term degradation. DHMs are a measure for the accumulated heat stress exerted on coral reefs due to elevated SST (see Fig. S6 for a graphical illustration of the methodology). Within a 4-month moving window the monthly SST above a reference value (here the mean of 
monthly maximal temperatures, MMM) are accumulated and compared to a threshold value (critical DHM threshold) that is associated with mass coral bleaching. The value of the critical DHM threshold depends on the scenario assumptions (see below). In order to translate coral bleaching events into long-term coral degradation, we refer to the assumption that reef recovery from mass coral bleaching is usually very limited within the first 5 years (Baker et al., 2008). Therefore, we assume a maximum tolerable probabilistic frequency of $0.2 \mathrm{yr}^{-1}$ (Donner, 2009) for bleaching events causing longterm degradation. The MMM is calculated from a 20 -year climatological reference period (1980-2000) individually for every coral location and SST pathway. Thus, the MMM serves as an indicator of temperatures to which the corals of a certain reef location are generally adapted. In order to generate a scenario-independent description of coral reef response to different levels of global warming (e.g. any given global mean air temperature pathway) we apply the algorithm to a large number of SST pathways and reassign the fraction of 2160 mapped coral reef locations subject to long-term degradation back to global air temperature pathways. In total, we use the SST pathways of 19 Atmosphere-Ocean General Circulation Models (AOGCMs) from the multi-model CMIP3 project and seven different emission scenarios leading to 30728 model years. We also used a wide range of critical DHMs (from 0 to $8^{\circ}$ ), which allows for the testing of risk scenarios with constant and variable critical DHM thresholds (e.g. thermal adaptation).

The condensed output of the global coral bleaching assessment allows for the implementation of different coral adaptation scenarios. In the standard scenario (Constant) a constant DHM threshold of $2{ }^{\circ} \mathrm{C}$ is assumed. This means that corals can resist a cumulative heat stress of $2{ }^{\circ} \mathrm{C}$ (accumulated over a 4-month period) above the long-term maximum monthly mean (MMM) sea surface temperature for a given location. It has been demonstrated that this value serves as a good proxy for severe mass coral bleaching (Donner et al., 2005, 2007).

In addition to the constant scenario, an extremely optimistic scenario of strong thermal adaptation of the corals is assessed (Adaptation). Under this scenario, the critical DHM threshold constantly increases from $2{ }^{\circ} \mathrm{C}$ in the year 2000 up to $6^{\circ} \mathrm{C}$ in 2100 . The assumption of a thermal adaptation of $0.4^{\circ}$ per decade appears very ambitious given the long creation times of reef-building corals and the consequently slow rate at which evolutionary adaptation occurs. Furthermore, additional environmental stressors such as ocean acidification (Caldeira, 2005) and disease spreading (Maynard et al., 2015) have to be expected to slow-down coral growth and to reduce the adaptive capacity of tropical coral reefs. As a consequence, this scenario should be seen as an absolute lower boundary for degradation of coral reefs globally.

Finally, a third scenario takes the negative effect of the acidification of the oceans into account which reduces the calcification rates of the corals and thus promotes further degradation of coral reefs (Saturation). We derived a trans- fer function based on atmospheric $\mathrm{CO}_{2}$ concentrations due to the fact that tropical surface aragonite saturation levels are in equilibrium with atmospheric $\mathrm{CO}_{2}$ concentrations on a timescale of years to decades (Caldeira, 2005). With an assumption of the effect of the aragonite saturation on the critical DHM threshold (see supporting material of Frieler et al., 2012) this translates into a measurable increased stress to corals.

\subsection{Results}

Coral reef systems are slow-growing, complex ecosystems that are particularly susceptible to the impacts of increased $\mathrm{CO}_{2}$ concentrations, both through warming (and resulting coral bleaching) and ocean acidification (Pörtner et al., 2014). Our analysis reiterates earlier findings that the risk of coral reefs to suffer from long-term degradation eventually leading to an ecosystem regime shift (Graham et al., 2015) will be substantial as early as 2030 (Meissner et al., 2012; Gattuso et al., 2015; Frieler et al., 2012). We find that this risk increases dramatically until the 2050s, where even under a $1.5^{\circ} \mathrm{C}$ scenario, $90 \%$ and more of all global reef grid cells will be at risk of long-term degradation under all but the most optimistic scenario assessed (the Adaptation case, see Sect. 7.1). However, long-term risks towards the end of the century are reduced to about $70 \%$ of global coral reef cells under a $1.5^{\circ} \mathrm{C}$ scenario but not under a $2{ }^{\circ} \mathrm{C}$ scenario (compare Fig. 14 and Table 3).

Our approach only includes the effects of increased $\mathrm{CO}_{2}$ concentrations, but does not account for other stressors for coral reef systems such as rising sea-levels, increased intensity of ENSO-events (Power et al., 2013), tropical cyclones (Knutson et al., 2010), invasive species and disease spreading (Maynard et al., 2015), and other local anthropogenic stressors, which ranks our projections of long-term coral reef degradation rather conservative. These projected losses will greatly affect societies, which depend on coral reefs as a primary source of ecosystem services, e.g. in the fishery and tourism sector (Cinner et al., 2016). Teh et al. (2013) estimate that about $25 \%$ of the world's small-scale fishers fish on coral reefs. Chen et al. (2015) report that a loss of less than $60 \%$ of global coral reef coverage, that could very well be reached already in the 2030s, would inflict damages of more than USD 20 billion annually.

\section{Discussion and conclusions}

The findings of our analysis support the IPCC AR5 Working Group 2 RFC assessment of differences in key impacts of climate change between warming of 1.5 and $2{ }^{\circ} \mathrm{C}$ above preindustrial levels: we find that under a $1.5^{\circ}$ scenario, the fractions of coral reef cells at risk of severe degradation are reduced significantly compared to a warming of $2{ }^{\circ} \mathrm{C}$ (RFC1), that the difference between 1.5 and $2{ }^{\circ} \mathrm{C}$ marks the transition between an upper limit of present-day natural variability 


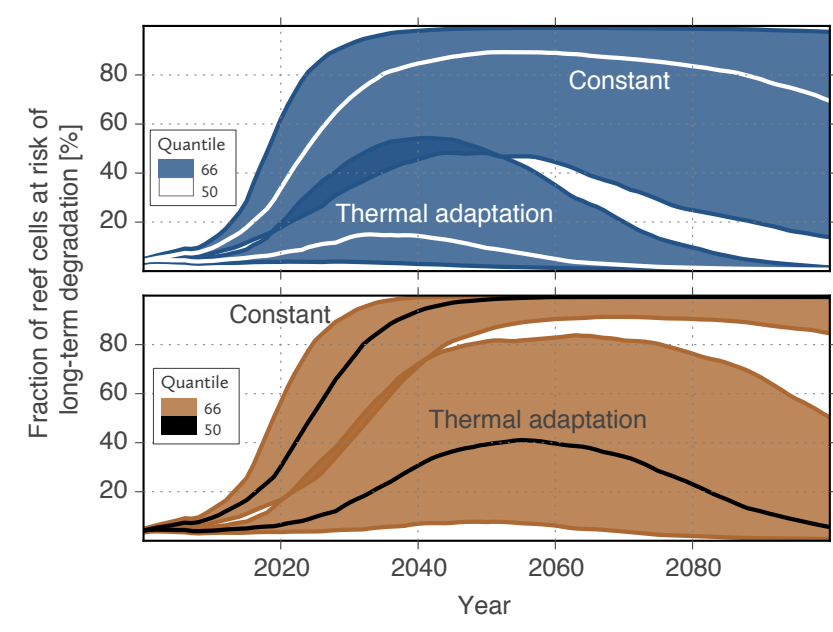

Figure 14. Probabilistic projections of the fraction of global tropical coral reef cells suffering from long-term degradation under two illustrative $1.5^{\circ} \mathrm{C}$ (upper panel) and $2{ }^{\circ} \mathrm{C}$ (lower panel) scenarios (see Fig. 13, upper panel) for two different assumptions about their adaptive capacity (see Sect. 7.1). Median projections and the $66 \%$ range are shown. Note that uncertainties also include uncertainties in the GMT response (see Fig. 13). See Sect. 7.1 for further details on the methodology. Only the projections for the Constant and Adaptation scenario are shown, since the projections for the Saturation scenario differ only slightly from Constant. Table 3 gives results for all three scenarios assessed.

and a new climate regime in terms of heat extremes globally (RFC2), and that changes in water availability and local agricultural yields are already unevenly distributed between world regions at $1.5^{\circ} \mathrm{C}$ and even more so at $2{ }^{\circ} \mathrm{C}$ (RFC3). Central findings across the different indicators studied are summarized in Fig. 15 and regional summaries are given in the Supplement (Figs. S7-S33).

Water availability reduction and dry spell length (CDD) increase are found to accelerate between $1.5^{\circ} \mathrm{C}$ and $2{ }^{\circ} \mathrm{C}$ for several sub-tropical regions, in particular in the Mediterranean, Central America and the Caribbean, South Africa and Australia. Local agriculture production in tropical regions is projected to be strongly affected by ongoing warming, and even more so, if effects of $\mathrm{CO}_{2}$-fertilization do not play out as current models project them or are counter-balanced by other factors such as nitrogen and phosphor limitations or heat stress, which are not fully included in the models investigated here. Given the substantial divergence in projections of specifically extreme temperature events between 1.5 and $2{ }^{\circ} \mathrm{C}$, this renders our estimates of respective crop yield differences rather conservative.

Our analysis of projected SLR reveals differences of about $10 \mathrm{~cm}$ in global mean SLR between illustrative $1.5^{\circ} \mathrm{C}$ and $2{ }^{\circ} \mathrm{C}$ scenarios by 2100 . In addition, the end-of-century rate of sea-level rise for $1.5^{\circ} \mathrm{C}$ is about $30 \%$ lower than for a $2{ }^{\circ} \mathrm{C}$ pathway, indicating a substantially lower long-term sealevel rise commitment (Clark et al., 2016). Evidence from
Table 3. Fraction of reef cells at risk of long-term degradation due to coral bleaching in 2050 and 2100 for three different assumptions about the adaptive capacity and susceptibility of corals to ocean acidification as described in Sect. 7.1 in percent. Median projections and the $66 \%$ range (in square brackets) are given, accounting also for uncertainties in global mean temperature projections.

\begin{tabular}{lll}
\hline & $1.5^{\circ} \mathrm{C}$ & $2{ }^{\circ} \mathrm{C}$ \\
\hline \multicolumn{3}{c}{2050} \\
\hline Adaptation & $9[2,49]$ & $39[8,81]$ \\
Saturation & $94[60,100]$ & $100[95,100]$ \\
Constant & $89[48,99]$ & $98[86,100]$ \\
\hline \multicolumn{3}{c}{2100} \\
\hline Adaptation & $1[0,2]$ & $6[1,50]$ \\
Saturation & $69[14,98]$ & $100[91,100]$ \\
Constant & $69[14,98]$ & $99[85,100]$ \\
\hline
\end{tabular}

the paleo-record (Dutton et al., 2015) and modelling studies (Levermann et al., 2013) further indicate that a multi-metre sea-level of potentially up to $9 \mathrm{~m}$ cannot be ruled out under a $2{ }^{\circ} \mathrm{C}$ warming on multi-millennial timescales.

Our assessment based on this limited set of indicators implies that differences in climate impacts between $1.5^{\circ} \mathrm{C}$ and $2{ }^{\circ} \mathrm{C}$ are most pronounced for particularly vulnerable regions and societal groupings with limited adaptive capacity (Olsson et al., 2014). Under a $2^{\circ} \mathrm{C}$ warming, coastal tropical regions and islands may face the combined effects of a near-complete loss of tropical coral reefs, which provide coastal protection and are a main source of ecosystem services, on-going sea-level rise above present-day rates over the 21 st century and increased threats by coastal flooding and inundation. The risks posed by extreme heat and potential crop yield reductions in tropical regions in Africa and SouthEast Asia under a $2{ }^{\circ} \mathrm{C}$ warming are particularly critical given the projected trends in population growth and urbanization in these regions (O'Neill et al., 2013). In conjunction with other development challenges, the impacts of climate change represent a fundamental challenge for regional food security (Lobell and Tebaldi, 2014) and may trigger new poverty traps for several countries or populations within countries (Olsson et al., 2014).

Furthermore, the emergence of the Mediterranean region, including North Africa and the Levant, as a hot-spot for reductions in water availability and dry spell increases between $1.5^{\circ} \mathrm{C}$ and $2{ }^{\circ} \mathrm{C}$ is of great relevance given the specific vulnerability of this region to water scarcity (Schellnhuber et al., 2014). The political instability in several countries in this region may further exacerbate the vulnerability of societies to climatic stresses, potentially increasing the risk of violent conflict outbreak (Kelley et al., 2015).

Taken together, we provide a consistent and comprehensive assessment of existing projections and a solid foundation 


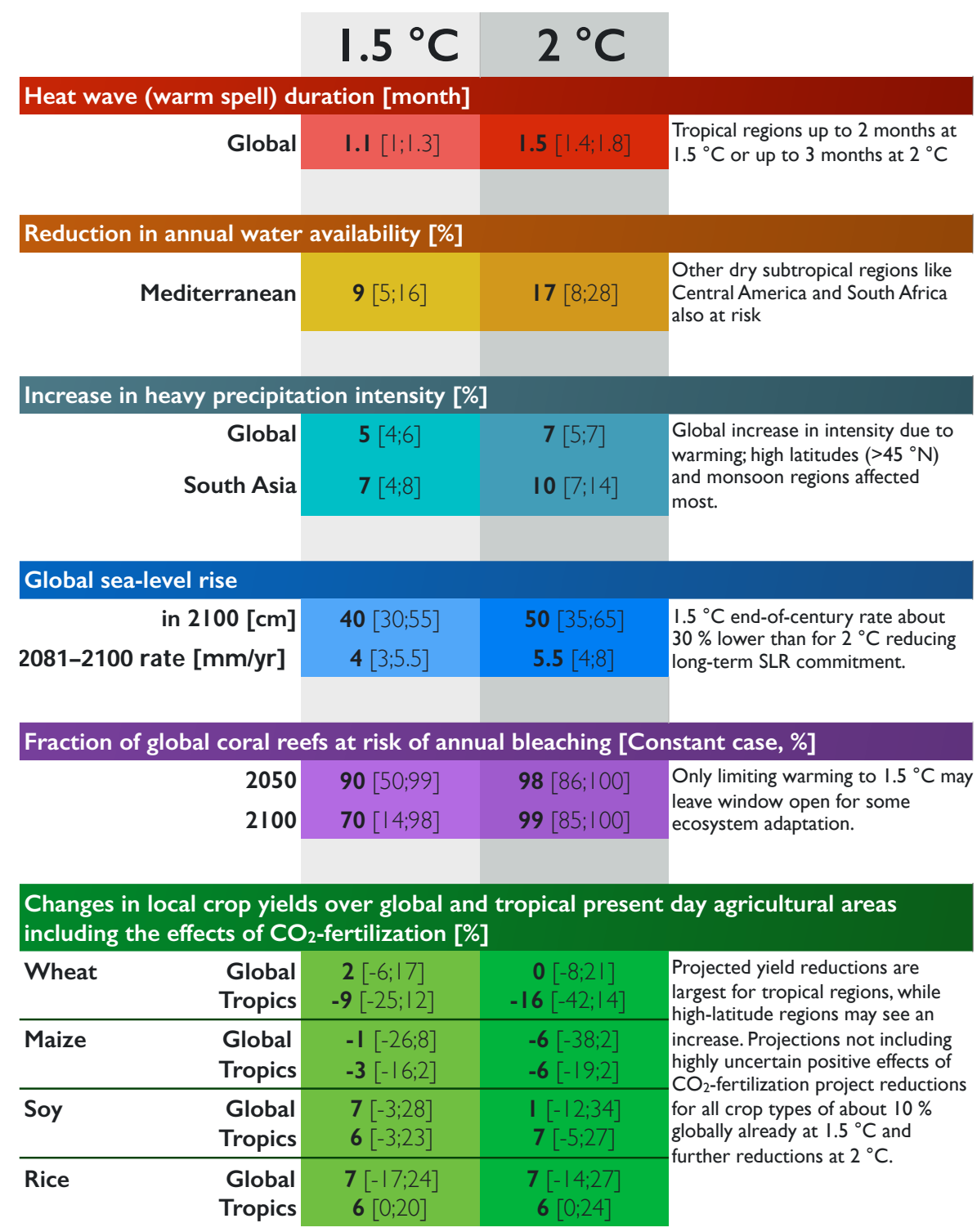

Figure 15. Summary of key differences in climate impacts between a warming of $1.5^{\circ} \mathrm{C}$ and $2{ }^{\circ} \mathrm{C}$ above pre-industrial and stylized $1.5^{\circ} \mathrm{C}$ and $2{ }^{\circ} \mathrm{C}$ scenarios over the 21 st century. Square brackets give the likely $(66 \%)$ range.

for future work on refining our understanding of the difference between impacts at $1.5^{\circ} \mathrm{C}$ and $2^{\circ} \mathrm{C}$ warming. In particular, we illustrate how limiting warming to $1.5^{\circ} \mathrm{C}$ would "significantly reduce the risks and impacts of climate change" as stated in the Paris Agreement. However, our analysis can only be a first step towards a more integrative post-Paris science agenda including the assessment of below $1.5^{\circ} \mathrm{C} \mathrm{im}$ pacts and requirements and costs of energy system transformation pathways in line with limiting warming to below $1.5^{\circ} \mathrm{C}$ (Rogelj et al., 2015).

\section{The Supplement related to this article is available online} at doi:10.5194/esd-7-327-2016-supplement.
Acknowledgements. We acknowledge the World Climate Research Programme's Working Group on Coupled Modelling, which is responsible for CMIP, and we thank the climate modelling groups for producing and making available their model output. For CMIP, the US Department of Energy's Program for Climate Model Diagnosis and Intercomparison provided coordinating support and led development of software infrastructure in partnership with the Global Organization for Earth System Science Portals. We would like to thank the modelling groups that participated in the InterSectoral Impact Model Intercomparison Project (ISI-MIP).

The ISI-MIP Fast Track project underlying this paper was funded by the German Federal Ministry of Education and Research with project funding reference number 01LS1201A. The work was supported by the German Federal Ministry for the Environment, Nature Conservation and Nuclear Safety (11-II-093-Global-A SIDS and 
LDCs), within the framework of the Leibniz Competition (SAW2013-PIK-5), from EU FP7 project HELIX (grant no. FP7-6038642), and by the German Federal Ministry of Education and Research (BMBF, grant no. 01LS1201A1).

We would like to thank two anonymous reviewers and the handling editor for their comments and suggestions that greatly helped to improve the manuscript.

Edited by: S. Smith

\section{References}

Asseng, S., Ewert, F., Martre, P., Rötter, R., Lobell, D., Cammarano, D., Kimball, B. A., Ottman, M., Wall, G., White, J., Reynolds, M., Alderman, P., Prasad, P., Aggarwal, P., Anothai, J., Basso, B., Biernath, C., Challinor, A., De Sanctis, G., Doltra, J., Fereres, E., Garcia-Vila, M., Gayler, S., Hoogenboom, G., Hunt, L., Izaurralde, R., Jabloun, M., Jones, C., Kersebaum, K., Koehler, A.-K., Müller, C., Naresh Kumar, S., Nendel, C., O'Leary, G., Olesen, J., Palosuo, T., Priesack, E., Eyshi Rezaei, E., Ruane, A., Semenov, M., Shcherbak, I., Stöckle, C., Stratonovitch, P., Streck, T., Supit, I., Tao, F., Thorburn, P., Waha, K., Wang, E., Wallach, D., Wolf, J., Zhao, Z., and Zhu, Y.: Rising temperatures reduce global wheat production, Nat. Clim. Change, 5, 143-147, doi:10.1038/nclimate2470, 2014.

Ault, T. R., Cole, J. E., Overpeck, J. T., Pederson, G. T., and Meko, D. M.: Assessing the risk of persistent drought using climate model simulations and paleoclimate data, J. Climate, 27, 75297549, doi:10.1175/JCLI-D-12-00282.1, 2014.

Baker, A. C., Glynn, P. W., and Riegl, B.: Climate change and coral reef bleaching: An ecological assessment of long-term impacts, recovery trends and future outlook, Estuar. Coast. Shelf Sci., 435-471, 2008. doi:10.1007/s00382-012-1408-y, 2012.

Bindschadler, R. A., Nowicki, S., Abe-OUCHI, A., Aschwanden, A., Choi, H., Fastook, J., Granzow, G., Greve, R., Gutowski, G., Herzfeld, U., Jackson, C., Johnson, J., Khroulev, C., Levermann, A., Lipscomb, W. H., Martin, M. A., Morlighem, M., Parizek, B. R., Pollard, D., Price, S. F., Ren, D., Saito, F., Sato, T., Seddik, H., Seroussi, H., Takahashi, K., Walker, R., and Wang, W. L.: Icesheet model sensitivities to environmental forcing and their use in projecting future sea level (the SeaRISE project), J. Glaciol., 59, 195-224, doi:10.3189/2013JoG12J125, 2013.

Bodirsky, B. L. and Müller, C.: Robust relationship between yields and nitrogen inputs indicates three ways to reduce nitrogen pollution, Environ. Res. Lett., 9, 111005, doi:10.1088/17489326/9/11/111005, 2014.

Bodirsky, B. L., Popp, A., Lotze-Campen, H., Dietrich, J. P., Rolinski, S., Weindl, I., Schmitz, C., Müller, C., Bonsch, M., Humpenöder, F., Biewald, A., and Stevanovic, M.: Reactive nitrogen requirements to feed the world in 2050 and potential to mitigate nitrogen pollution, Nat. Commun., 5, 3858, doi:10.1038/ncomms4858, 2014.

Boers, N., Bookhagen, B., Barbosa, H., Marwan, N., and Kurths, J.: Prediction of extreme floods in the Central Andes by means of Complex Networks, Nat. Commun., 16, 7173, doi:10.1038/ncomms6199, 2014.

Caldeira, K.: Ocean model predictions of chemistry changes from carbon dioxide emissions to the atmosphere and ocean, J. Geophys. Res., 110, 1-12, doi:10.1029/2004JC002671, 2005.
Chadwick, R. and Good, P.: Understanding nonlinear tropical precipitation responses to $\mathrm{CO}_{2}$ forcing, Geophys. Res. Lett., 40, 4911-4915, doi:10.1002/grl.50932, 2013.

Chen, P.-Y., Chen, C.-C., Chu, L., and Mccarl, B.: Evaluating the economic damage of climate change on global coral reefs, Global Environ. Change, 30, 12-20, doi:10.1016/j.gloenvcha.2014.10.011, 2015.

Church, J. A., Clark, P. U., Cazenave, A., Gregory, J. M., Jevrejeva, S., Levermann, A., Merrifield, M. A., Milne, G. A., Nerem, R. S., Nunn, P. D., Payne, A. J., Pfeffer, W. T., Stammer, D., and Unnikrishnan, A. S.: Sea Level Change, in: Climate Change 2013: The Physical Science Basis, Contribution of Working Group I to the Fifth Assessment Report of the Intergovernmental Panel on Climate, edited by: Stocker, T. F., Qin, D., Plattner, G.-K., Tignor, M., Allen, S. K., Boschung, J., Nauels, A., Xia, Y., Bex, V., and Midgley, P. M., Cambridge University Press, Cambridge, UK and New York, NY, USA, 2013.

Cinner, J. E., Pratchett, M. S., Graham, N. A. J., Messmer, V., Fuentes, M. M. P. B., Ainsworth, T., Ban, N., Bay, L. K., Blythe, J., Dissard, D., Dunn, S., Evans, L., Fabinyi, M., Fidelman, P., Figueiredo, J., Frisch, A. J., Fulton, C. J., Hicks, C. C., Lukoschek, V., Mallela, J., Moya, A., Penin, L., Rummer, J. L., Walker, S., and Williamson, D. H.: A framework for understanding climate change impacts on coral reef social-ecological systems, Reg. Environ. Change, 16, 11331146 doi:10.1007/s10113-015-0832-z, 2016.

Clark, P. U., Shakun, J. D., Marcott, S. A., Mix, A. C., Eby, M., Kulp, S., Levermann, A., Milne, G. A., Pfister, P. L., Santer, B. D., Schrag, D. P., Solomon, S., Stocker, T. F., Strauss, B. H., Weaver, A. J., Winkelmann, R., Archer, D., Bard, E., Goldner, A., Lambeck, K., Pierrehumbert, R. T., and Plattner, G.-K.: Consequences of twenty-first-century policy for multi-millennial climate and sea-level change, Nat. Clim. Change, 6, 360-369, doi:10.1038/nclimate2923, 2016.

Coumou, D. and Robinson, A.: Historic and future increase in the global land area affected by monthly heat extremes, Environ. Res. Lett., 8, 034018, doi:10.1088/1748-9326/8/3/034018, 2013.

Dai, A.: Increasing drought under global warming in observations and models, Nat. Clim. Change, 3, 52-58, doi:10.1038/nclimate1633, 2012.

Deryng, D., Conway, D., Ramankutty, N., Price, J., and Warren, R.: Global crop yield response to extreme heat stress under multiple climate change futures, Environ. Res. Lett., 9, 034011, doi:10.1088/1748-9326/9/3/034011, 2014.

Diffenbaugh, N. S. and Scherer, M.: Observational and model evidence of global emergence of permanent, unprecedented heat in the 20th and 21st centuries, Climatic Change, 107, 615-624, doi:10.1007/s10584-011-0112-y, 2011.

Donner, S. D.: Coping with commitment: projected thermal stress on coral reefs under different future scenarios, PloS One, 4, e5712, doi:10.1371/journal.pone.0005712, 2009.

Donner, S. D., Skirving, W. J., Little, C. M., Oppenheimer, M., and Hoegh-Gulberg, O.: Global assessment of coral bleaching and required rates of adaptation under climate change, Global Change Biol., 11, 2251-2265, doi:10.1111/j.1365-2486.2005.01073.x, 2005.

Donner, S. D., Knutson, T. R., and Oppenheimer, M.: Model-based assessment of the role of human-induced climate change in the 
2005 Caribbean coral bleaching event, P. Natl. Acad. Sci., 104, 5483-5488, doi:10.1073/pnas.0610122104, 2007.

Dutton, A., Carlson, A. E., Long, A. J., Milne, G. A., Clark, P. U., DeConto, R., Horton, B. P., Rahmstorf, S., and Raymo, M. E.: Sea-level rise due to polar ice-sheet mass loss during past warm periods, Science, 349, 6244, doi:10.1126/science.aaa4019, 2015.

Eamus, D.: The interaction of rising $\mathrm{CO}_{2}$ and temperatures with water use efficiency, Plant Cell Environ., 14, 843-852, doi:10.1111/j.1365-3040.1991.tb01447.x, 1991.

Favier, L., Durand, G., Cornford, S. L., Gudmundsson, G. H., Gagliardini, O., Gillet-Chaulet, F., Zwinger, T., Payne, A. J., and Le Brocq, A. M.: Retreat of Pine Island Glacier controlled by marine ice-sheet instability, Nat. Clim. Change, 4, 117-121, doi:10.1038/nclimate2094, 2014.

Feldmann, J., Levermann, A.: Collapse of the West Antarctic Ice Sheet after local destabilization of the Amundsen Basin, P. Natl. Acad. Sci., 112, 14191-14196, doi:10.1073/pnas.1512482112, 2015.

Fettweis, X., Franco, B., Tedesco, M., van Angelen, J. H., Lenaerts, J. T. M., van den Broeke, M. R., and Gallée, H.: Estimating the Greenland ice sheet surface mass balance contribution to future sea level rise using the regional atmospheric climate model MAR, The Cryosphere, 7, 469-489, doi:10.5194/tc-7-469-2013, 2013

Fischer, E.M. and Knutti, R.: Detection of spatially aggregated changes in temperature and precipitation extremes, Geophys. Res. Lett., 41, doi:10.1002/2013GL058499, 2014.

Fischer, E. M., Beyerle, U., and Knutti, R.: Robust spatially aggregated projections of climate extremes, Nat. Clim. Change, 3, 1033-1038, doi:10.1038/nclimate2051, 2013.

Flato, G., Marotzke, J., Abiodun, B., Braconnot, P., Chou, S. C., Collins, W., Cox, P., Driouech, F., Emori, S., Eyring, V., Forest, C., Gleckler, P., Guilyardi, E., Jakob, C., Kattsov, V., Reason, C., and Rummukainen, M.: Evaluation of Climate Models, book section 9, Cambridge University Press, Cambridge, UK and New York, NY, USA, 741-866, doi:10.1017/CBO9781107415324.020, 2013.

Frieler, K., Meinshausen, M., Golly, A., Mengel, M., Lebek, K., Donner, S. D., and Hoegh-Guldberg, O.: Limiting global warming to ${ }^{2} \mathrm{C}$ is unlikely to save most coral reefs, Nat. Clim. Change, 3, 165-170, doi:10.1038/nclimate1674, 2012.

Frieler, K., Levermann, A., Elliott, J., Heinke, J., Arneth, A., Bierkens, M. F. P., Ciais, P., Clark, D. B., Deryng, D., Döll, P., Falloon, P., Fekete, B., Folberth, C., Friend, A. D., Gellhorn, C., Gosling, S. N., Haddeland, I., Khabarov, N., Lomas, M., Masaki, Y., Nishina, K., Neumann, K., Oki, T., Pavlick, R., Ruane, A. C., Schmid, E., Schmitz, C., Stacke, T., Stehfest, E., Tang, Q., Wisser, D., Huber, V., Piontek, F., Warszawski, L., Schewe, J., Lotze-Campen, H., and Schellnhuber, H. J.: A framework for the cross-sectoral integration of multi-model impact projections: land use decisions under climate impacts uncertainties, Earth Syst. Dynam., 6, 447-460, doi:10.5194/esd-6-447-2015, 2015.

Gattuso, J.-P., Magnan, A., Bille, R., Cheung, W. W. L., Howes, E. L., Joos, F., Allemand, D., Bopp, L., Cooley, S. R., Eakin, C. M., Hoegh-Guldberg, O., Kelly, R. P., Portner, H.-O., Rogers, A. D., Baxter, J. M., Laffoley, D., Osborn, D., Rankovic, A., Rochette, J., Sumaila, U. R., and Treyer, S.: Contrasting futures for ocean and society from different anthropogenic $\mathrm{CO}_{2}$ emissions scenarios, Science, 349, aac4722, doi:10.1126/science.aac4722, 2015.

Gourdji, S. M., Sibley, A. M., and Lobell, D. B.: Global crop exposure to critical high temperatures in the reproductive period: historical trends and future projections, Environ. Res. Lett., 8, 024041, doi:10.1088/1748-9326/8/2/024041, 2013.

Graham, N. A. J., Jennings, S., Macneil, M. A., Mouillot, D., and Wilson, S. K.: Predicting climate-driven regime shifts versus rebound potential in coral reefs, Nature, 518, 94-97, doi:10.1038/nature14140, 2015.

Gregory, J. M. and Huybrechts, P.: Ice-sheet contributions to future sea-level change, Philos. T. Roy. Soc. A, 364, 1709-1732, doi:10.1098/rsta.2006.1796, 2006.

Hansen, J., Sato, M., and Ruedy, R.: PNAS Plus: Perception of climate change, P. Natl. Acad. Sci., 109, E2415-E2423, doi:10.1073/pnas.1205276109, 2012.

Hawkins, E., Joshi, M., and Frame, D.: Wetter then drier in some tropical areas, Nat. Clim. Change, 4, 646-647, doi:10.1038/nclimate2299, 2014.

Held, I. M. and Soden, B. J.: Robust Responses of the Hydrological Cycle to Global Warming, J. Climate, 19, 5686-5699, 2006.

Hellmer, H. H., Kauker, F., Timmermann, R., Determann, J., and Rae, J.: Twenty-first-century warming of a large Antarctic iceshelf cavity by a redirected coastal current, Nature, 485, 225228, doi:10.1038/nature11064, 2012.

Hempel, S., Frieler, K., Warszawski, L., Schewe, J., and Piontek, F.: A trend-preserving bias correction - the ISI-MIP approach, Earth Syst. Dynam., 4, 219-236, doi:10.5194/esd-4-219-2013, 2013.

Herger, N., Sanderson, B. M., and Knutti, R.: Improved pattern scaling approaches for the use in climate impact studies, Geophys. Res. Lett., 42, 3486-3494, doi:10.1002/2015GL063569, 2015.

Hinkel, J., Lincke, D., Vafeidis, A. T., Perrette, M., Nicholls, R. J., Tol, R. S. J., Marzeion, B., Fettweis, X., Ionescu, C., and Levermann, A.: Coastal flood damage and adaptation costs under 21st century sea-level rise, P. Natl. Acad. Sci., 111, 3292-3297, doi:10.1073/pnas.1222469111, 2014.

Hirabayashi, Y., Mahendran, R., Koirala, S., Konoshima, L., Yamazaki, D., Watanabe, S., Kim, H., and Kanae, S.: Global flood risk under climate change, Nat. Clim. Change, 3, 1-6, doi:10.1038/nclimate1911, 2013.

IPCC: Managing the Risks of Extreme Events and Disasters to Advance Climate Change Adaptation, in: A Special Report of Working Groups I and II of the Intergovernmental Panel on Climate Change, edited by: Field, C. B., Barros, V., Stocker, T. F., Qin, D., Dokken, D. J., Ebi, K. L., Mastrandrea, M. D., Mach, K. J., Plattner, G.-K., Allen, S. K., Tignor, M., and Midgley, P. M., Cambridge University Press, Cambridge, UK, and New York, NY, USA, 582 pp., 2012.

IPCC: Summary for Policymakers, in: Climate Change 2013: The Physical Science Basis, Contribution of Working Group I to the Fifth Assessment Report of the Intergovernmental Panel on Climate Change, edited by: Stocker, T., Qin, D., Plattner, G.-K., Tignor, M., Allen, S., Boschung, J., Nauels, A., Xia, Y., Bex, V., and Midgley, P., IPCC AR WGI, Cambridge University Press, Cambridge, UK and New York, NY, USA, 1-100, 2013.

IPCC: Climate Change 2014: Synthesis Report, in: Contribution of Working Groups I, II and III to the Fifth Assessment Report of the Intergovernmental Panel on Climate Change, IPCC Geneva, Switzerland, 151 pp., 2014a. 
IPCC: Summary for Policy Makers, in: Climate Change 2014: Impacts, Adaptation and Vulnerability - Contributions of the Working Group II to the Fifth Assessment Report, edited by: Field, C. B., Barros, V. R., Dokken, D., Mach, K. J., Mastrandrea, M. D., Bilir, T. E., Chatterjee, M., Ebi, K. L., Estrada, Y., Genova, R., Girma, B., Kissel, E., Levy, A., MacCracken, S., Mastrandrea, P. R., and White, L., Cambridge University Press, Cambridge, UK and New York, NY, USA, 1-32, doi:10.1016/j.renene.2009.11.012, 2014b.

James, R. and Washington, R.: Changes in African temperature and precipitation associated with degrees of global warming, Climatic Change, 117, 859-872, doi:10.1007/s10584-012-0581-7, 2013.

Jiménez Cisneros, B. E., Oki, T., Arnell, N. W., Benito, G., Cogley, J G., Döll, P., Jiang, T., Mwakalila, S. S.: Freshwater resources, in: Climate Change 2014: Impacts, Adaptation, and Vulnerability, Part A: Global and Sectoral Aspects, Contribution of Working Group II to the Fifth Assessment Report of the Intergovernmental Panel of Climate Change, edited by: Field, C. B., Barros, V. R., Dokken, D. J., Mach, K. J., Mastrandrea, M. D., Bilir, T. E., Chatterjee, M., Ebi, K. L., Estrada, Y. O., Genova, R. C., Girma, B., Kissel, E. S., Levy, A. N., MacCracken, S., Mastrandrea, P. R., and White, L. L., Cambridge University Press, Cambridge, UK and New York, NY, USA, 229-269, 2014.

Joughin, I., Smith, B. E., and Medley, B.: Marine Ice Sheet Collapse Potentially Underway for the Thwaites Glacier Basin, West Antarctica, Science, 344, 735-388, doi:10.1126/science.1249055, 2014.

Kelley, C. P., Mohtadi, S., Cane, M. A., Seager, R., and Kushnir, Y.: Climate change in the Fertile Crescent and implications of the recent Syrian drought, P. Natl. Acad. Sci. USA, 112, 3241-3246 doi:10.1073/pnas.1421533112, 2015.

Kendon, E. J., Rowell, D. P., Jones, R. G., and Buonomo, E.: Robustness of Future Changes in Local Precipitation Extremes, J. Climate, 21, 4280-4297, doi:10.1175/2008JCLI2082.1, 2008.

Kharin, V. V., Zwiers, F. W., Zhang, X., and Wehner, M.: Changes in temperature and precipitation extremes in the CMIP5 ensemble, Climatic Change, 119, 345-357, doi:10.1007/s10584-013-07058, 2013.

Kiem, A. and Verdon-Kidd, D.: Towards understanding hydroclimatic change in Victoria, Australia - preliminary insights into the "Big Dry", Hydrol. Earth Syst. Sci., 14, 433-445, doi:10.5194/hess-14-433-2010, 2010.

King, A. D., Donat, M. G., Fischer, E. M., Hawkins, E., Alexander, L. V., Karoly, D. J., Dittus, A. J., Lewis, S. C., and Perkins, S. E.: The timing of anthropogenic emergence in simulated climate extremes, Environ. Res. Lett., 10, 094015, doi:10.1088/17489326/10/9/094015, 2015.

Knutson, T. R., McBride, J. L., Chan, J., Emanuel, K., Holland, G., Landsea, C., Held, I., Kossin, J. P., Srivastava, A. K., and Sugi, M.: Tropical cyclones and climate change, Nat. Geosci., 3, 157163, doi:10.1038/ngeo779, 2010.

Knutti, R. and Sedláček, J.: Robustness and uncertainties in the new CMIP5 climate model projections, Nat. Clim. Change, 3, 369373, doi:10.1038/nclimate1716, 2012.

Knutti, R., Rogelj, J., Sedláček, J., and Fischer, E. M.: A scientific critique of the two-degree climate change target, Nat. Geosci., 9, 13-18, doi:10.1038/ngeo2595, 2015.
Leakey, A. D. B., Uribelarrea, M., Ainsworth, E. A., Naidu, S. L., Rogers, A., Ort, D. R., and Long, S. P.: Photosynthesis, productivity, and yield of maize are not affected by open-air elevation of $\mathrm{CO}_{2}$ concentration in the absence of drought, Plant Physiol., 140, 779-790, doi:10.1104/pp.105.073957, 2006.

Lesk, C., Rowhani, P., and Ramankutty, N.: Influence of extreme weather disasters on global crop production, Nature, 529, 84-87, doi:10.1038/nature16467, 2016.

Levermann, A., Clark, P. U., Marzeion, B., Milne, G. A., Pollard, D., Radic, V., and Robinson, A.: The multimillennial sea-level commitment of global warming, P. Natl. Acad. Sci. USA, 110, 13745-13750, doi:10.1073/pnas.1219414110, 2013.

Levermann, A., Winkelmann, R., Nowicki, S., Fastook, J. L., Frieler, K., Greve, R., Hellmer, H. H., Martin, M. A., Meinshausen, M., Mengel, M., Payne, A. J., Pollard, D., Sato, T., Timmermann, R., Wang, W. L., and Bindschadler, R. A.: Projecting Antarctic ice discharge using response functions from SeaRISE ice-sheet models, Earth Syst. Dynam., 5, 271-293, doi:10.5194/esd-5-271-2014, 2014.

Lobell, D. B. and Tebaldi, C.: Getting caught with our plants down: the risks of a global crop yield slowdown from climate trends in the next two decades, Environ. Res. Lett., 9, 074003, doi:10.1088/1748-9326/9/7/074003, 2014.

Lobell, D. B., Sibley, A., and Ivan Ortiz-Monasterio, J.: Extreme heat effects on wheat senescence in India, Nat. Clim. Change, 2, 186-189, doi:10.1038/nclimate1356, 2012.

Lopez, A., Suckling, E. B., and Smith, L. A.: Robustness of pattern scaled climate change scenarios for adaptation decision support, Climatic Change, 122, 555-566, doi:10.1007/s10584-013-1022y, 2013.

Marotzke, J. and Forster, P. M.: Forcing, feedback and internal variability in global temperature trends, Nature, 517, 565-570, doi:10.1038/nature14117, 2014.

Maynard, J., van Hooidonk, R., Eakin, C. M., Puotinen, M., Garren, M., Williams, G., Heron, S. F., Lamb, J., Weil, E., Willis, B., and Harvell, C. D.: Projections of climate conditions that increase coral disease susceptibility and pathogen abundance and virulence, Nat. Clim. Change, 5, 688-694, doi:10.1038/nclimate2625, 2015.

McGrath, J. M. and Lobell, D. B.: Regional disparities in the $\mathrm{CO}_{2}$ fertilization effect and implications for crop yields, Environ. Res. Lett., 8, 014054, doi:10.1088/1748-9326/8/1/014054, 2013.

McSweeney, C. F. and Jones, R. G.: How representative is the spread of climate projections from the $5\{$ CMIP5 \{GCMs\} used in ISI-MIP?, Climate Services, 1, 24-29, doi:10.1016/j.cliser.2016.02.001, 2016.

Meehl, G., Stocker, T., Collins, W., Friedlingstein, P., Gaye, A., Gregory, J., Kitoh, A., Knutti, R., Murphy, J., Noda, A., Raper, S., Watterson, I., Weaver, A., and Zhao, Z.-C.: Global climate projections, in: Climate Change 2007: The Physical Science Basis, Contribution of Working Group I to the Fourth Assessment Report of the Intergovernmental Panel on Climate Change, chap. 10, edited by: Solomon, S., Qin, D., Manning, M., Chen, Z., Marquis, M., Averyt, K., Tignor, M., and Miller, H., Cambridge University Press, Cambridge, UK and New York, NY, USA, 747-845, 2007.

Meinshausen, M., Meinshausen, N., Hare, W., Raper, S. C. B., Frieler, K., Knutti, R., Frame, D. J., and Allen, M. R.: 
Greenhouse-gas emission targets for limiting global warming to $2{ }^{\circ} \mathrm{C}$, Nature, 458, 1158-1162, doi:10.1038/nature08017, 2009.

Meinshausen, M., Raper, S. C. B., and Wigley, T. M. L.: Emulating coupled atmosphere-ocean and carbon cycle models with a simpler model, MAGICC6 - Part 1: Model description and calibration, Atmos. Chem. Phys., 11, 1417-1456, doi:10.5194/acp11-1417-2011, 2011.

Meissner, K. J., Lippmann, T., and Sen Gupta, A.: Large-scale stress factors affecting coral reefs: open ocean sea surface temperature and surface seawater aragonite saturation over the next 400 years, Coral Reefs, 31, 309-319, doi:10.1007/s00338-0110866-8, 2012.

Mengel, M. and Levermann, A.: Ice plug prevents irreversible discharge from East Antarctica, Nat. Clim. Change, 27, 1-5, doi:10.1038/NCLIMATE2226, 2014.

Monfreda, C., Ramankutty, N., and Foley, J.: Farming the planet: 2. Geographic distribution of crop areas, yields, physiological types, and net primary production in the year 2000, Global Biogeochem. Cy., 22, 1-19, doi:10.1029/2007GB002947, 2008.

Moore, F. C. and Lobell, D. B.: The fingerprint of climate trends on European crop yields, P. Natl. Acad. Sci., 112, 2670-2675 doi:10.1073/pnas.1409606112, 2015.

Mora, C., Frazier, A. G., Longman, R. J., Dacks, R. S., Walton, M. M., Tong, E. J., Sanchez, J. J., Kaiser, L. R., Stender, Y. O., Anderson, J. M., Ambrosino, C. M., Fernandez-Silva, I., Giuseffi, L. M., and Giambelluca, T. W.: The projected timing of climate departure from recent variability, Nature, 502, 183-187, doi:10.1038/nature12540, 2013.

Mueller, B. and Seneviratne, S. I.: Hot days induced by precipitation deficits at the global scale, P. Natl. Acad. Sci. USA, 109, 1239812403, doi:10.1073/pnas.1204330109, 2012.

Müller, C., Waha, K., Bondeau, A., and Heinke, J.: Hotspots of climate change impacts in sub-Saharan Africa and implications for adaptation and development, Global Change Biol., 20, 25052517, doi:10.1111/gcb.12586, 2014.

Olsson, L., Opondo, M., Tschakert, P., Agrawal, A., Eriksen, S. H., Ma, S., Perch, L. N., and Zakieldeen, S. A.: Livelihoods and poverty, in: Climate Change 2014: Impacts, Adaptation, and Vulnerability, Part A: Global and Sectoral Aspects. Contribution of Working Group II to the Fifth Assessment Report of the Intergovernmental Panel of Climate Change, edited by: Field, C. B., Barros, V. R., Dokken, D. J., Mach, K. J., Mastrandrea, M. D., Bilir, T. E., Chatterjee, M., Ebi, K. L., Estrada, Y. O., Genova, R. C., Girma, B., Kissel, E. S., Levy, A. N., MacCracken, S., Mastrandrea, P. R., and White, L. L., Cambridge University Press, Cambridge, UK and New York, NY, USA, 793-832, 2014.

O’Neill, B. C., Kriegler, E., Riahi, K., Ebi, K. L., Hallegatte, S., Carter, T. R., Mathur, R., and Vuuren, D. P.: A new scenario framework for climate change research: the concept of shared socioeconomic pathways, Climatic Change, 122, 387400, doi:10.1007/s10584-013-0905-2, 2013.

Oppenheimer, M., Campos, M., Warren, R., Birkmann, J., Luber, G., O’Neill, B., and Kikkawa, T.: Emergent Risks and Key Vulnerabilities, in: Climate Change 2014: Impacts, Adaptation, and Vulnerability, Part A: Global and Sectoral Aspects. Contribution of Working Group II to the Fifth Assessment Report of the Intergovernmental Panel on Climate Change, chap. 19, edited by: Field, C. B., Barros, V. R., Dokken, D., Mach, K. J., Mastrandrea, M. D., Bilir, T. E., Chatterjee, M., Ebi, K. L., Estrada, Y.,
Genova, R., Girma, B., Kissel, E., Levy, A., MacCracken, S., Mastrandrea, P. R., and White, L., Cambridge University Press, Cambridge, UK and New York, NY, USA, 1039-1099, 2014.

Orlowsky, B. and Seneviratne, S. I.: Global changes in extreme events: regional and seasonal dimension, Climatic Change, 110, 669-696, doi:10.1007/s10584-011-0122-9, 2012.

Perrette, M., Landerer, F., Riva, R., Frieler, K., and Meinshausen, M.: A scaling approach to project regional sea level rise and its uncertainties, Earth Syst. Dynam., 4, 11-29, doi:10.5194/esd-411-2013, 2013.

Porter, J., Liyong, X., Challinor, A., Cochrane, K., Howden, M., Iqbal, M., Lobell, D., and Travasso, M.: Food Security and Food Production Systems, in: IPCC 2014: Climate Change 2014: Impacts, Adaptation, and Vulnerability, Contribution of Working Group II to the Fifth Assessment Report of the Intergovernmental Panel on Climate Change, Chapter 7, Final Draft, October 2013, IPCC AR5 WGII, Cambridge University Press, Cambridge and New York, 1-82, 2014.

Pörtner, H.-O., Karl, D. M., Boyd, P. W., Cheung, W. W. L., LluchCota, S. E., Nojiri, Y., Schmidt, D. N., and Zavialov, P.: Ocean Systems, in: Climate Change 2014: Impacts, Adaptation, and Vulnerability. Part A: Global and Sectoral Aspects, Contribution of Working Group II to the Fifth Assessment Report of the Intergovernmental Panel on Climate Change, chap. 06, edited by: Field, C. B., Barros, V. R., Dokken, D., Mach, K. J., Mastrandrea, M. D., Bilir, T. E., Chatterjee, M., Ebi, K. L., Estrada, Y., Genova, R., Girma, B., Kissel, E., Levy, A., MacCracken, S., Mastrandrea, P. R., and White, L., Cambridge University Press, Cambridge, UK and New York, NY, USA, 411-484, 2014.

Power, S., Delage, F., Chung, C., Kociuba, G., and Keay, K.: Robust twenty-first-century projections of El Niño and related precipitation variability, Nature, 502, 541-545, doi:10.1038/nature12580, 2013.

Prudhomme, C., Giuntoli, I., Robinson, E. L., Clark, D. B., Arnell, N. W., Dankers, R., Fekete, B. M., Franssen, W., Gerten, D., Gosling, S. N., Hagemann, S., Hannah, D. M., Kim, H., Masaki, Y., Satoh, Y., Stacke, T., Wada, Y., and Wisser, D.: Hydrological droughts in the 21 st century, hotspots and uncertainties from a global multimodel ensemble experiment, P. Natl. Acad. Sci., 111, 3262-3267, doi:10.1073/pnas.1222473110, 2013.

Riahi, K., Grübler, A., and Nakicenovic, N.: Scenarios of long-term socio-economic and environmental development under climate stabilization, Technol. Forecast. Social Change, 74, 887-935, doi:10.1016/j.techfore.2006.05.026, 2007.

Rignot, E., Mouginot, J., Morlighem, M., Seroussi, H., and Scheuchl, B.: Widespread, rapid grounding line retreat of Pine Island, Thwaites, Smith, and Kohler glaciers, West Antarctica, from 1992 to 2011, Geophys. Res. Lett., 41, 3502-3509, doi:10.1002/2014GL060140, 2014.

Robinson, A., Calov, R., and Ganopolski, A.: Multistability and critical thresholds of the Greenland ice sheet, Nat. Clim. Change, 2, 429-432, doi:10.1038/nclimate1449, 2012.

Rogelj, J., Meinshausen, M., and Knutti, R.: Global warming under old and new scenarios using IPCC climate sensitivity range estimates, Nat. Clim. Change, 2, 248-253, doi:10.1038/nclimate1385, 2012.

Rogelj, J., McCollum, D. L., Reisinger, A., Meinshausen, M., and Riahi, K.: Probabilistic cost estimates for climate change mitigation, Nature, 493, 79-83, doi:10.1038/nature11787, 2013. 
Rogelj, J., Meinshausen, M., Sedláček, J., and Knutti, R.: Implications of potentially lower climate sensitivity on climate projections and policy, Environ. Res. Lett., 9, 031003, doi:10.1088/1748-9326/9/3/031003, 2014.

Rogelj, J., Luderer, G., Pietzcker, R. C., Kriegler, E., Schaeffer, M., Krey, V., and Riahi, K.: Energy system transformations for limiting end-of-century warming to below $1.5^{\circ} \mathrm{C}$, Nat. Clim. Change, 5, 519-527, doi:10.1038/nclimate2572, 2015.

Rosenzweig, C., Elliott, J., Deryng, D., Ruane, A. C., Müller, C., Arneth, A., Boote, K. J., Folberth, C., Glotter, M., Khabarov, N., Neumann, K., Piontek, F., Pugh, T. A. M., Schmid, E., Stehfest, E., Yang, H., and Jones, J. W.: Assessing agricultural risks of climate change in the 21 st century in a global gridded crop model intercomparison, P. Natl. Acad. Sci. USA, 11, 3268-3273, doi:10.1073/pnas.1222463110, 2014.

Schaeffer, M., Hare, W., Rahmstorf, S., and Vermeer, M.: Longterm sea-level rise implied by $1.5^{\circ} \mathrm{C}$ and $2{ }^{\circ} \mathrm{C}$ warming levels, Nat. Clim. Change, 2 , 867-870, doi:10.1038/nclimate1584, 2012.

Schellnhuber, H.-J., Hare, W. L., Serdeczny, O., Adams, S., Coumou, D., Frieler, K., Marin, M., Otto, I. M., Perrette, M., Robinson, A., Rocha, M., Schaeffer, M., Schewe, J., Wang, X., and Warszawski, L.: Turn Down the Heat: Why a $4{ }^{\circ} \mathrm{C}$ Warmer World Must be Avoided, Tech. rep., commissioned by the World Bank, Washington, D.C., 2012.

Schellnhuber, H. J., Hare, B., Serdeczny, O., Schaeffer, M., Adams, S., Baarsch, F., Schwan, S., Coumou, D., Robinson, A., Vieweg, M., and Others: Turn down the heat: climate extremes, regional impacts, and the case for resilience, Tech. rep., commissioned by the World Bank, Washington, D.C., 2013.

Schellnhuber, H. J., Reyer, C., Hare, B., Waha, K., Otto, I. M., Serdeczny, O., Schaeffer, M., Schleuß ner, C.-F., Reckien, D., Marcus, R., Kit, O., Eden, A., Adams, S., Aich, V., Albrecht, T., Baarsch, F., Boit, A., Canales Trujillo, N., Cartsburg, M., Coumou, D., Fader, M., Hoff, H., Jobbins, G., Jones, L., Krummenauer, L., Langerwisch, F., Le Masson, V., Ludi, E., Mengel, M., Möhring, J., Mosello, B., Norton, A., Perette, M., Pereznieto, P., Rammig, A., Reinhardt, J., Robinson, A., Rocha, M., Sakschewski, B., Schaphoff, S., Schewe, J., Stagl, J., and Thonicke, K.: Turn Down the Heat: Confronting the New Climate Normal, Tech. rep., commissioned by the World Bank, Washington, D.C., 2014.

Schewe, J., Heinke, J., Gerten, D., Haddeland, I., Arnell, N. W., Clark, D. B., Dankers, R., Eisner, S., Fekete, B. M., ColonGonzalez, F. J., Gosling, S. N., Kim, H., Liu, X., Masaki, Y., Portmann, F. T., Satoh, Y., Stacke, T., Tang, Q., Wada, Y., Wisser, D., Albrecht, T., Frieler, K., Piontek, F., Warszawski, L., and Kabat, P.: Multimodel assessment of water scarcity under climate change, P. Natl. Acad. Sci., 111, 3245-3250, doi:10.1073/pnas.1222460110, 2014.

Schleussner, C.-F., Levermann, A., and Meinshausen, M.: Probabilistic Projections of the Atlantic Overturning, 127, 579-586, doi:10.1007/s10584-014-1265-2, 2014

Schleussner, C. F., Runge, J., Lehmann, J., and Levermann, A.: The role of the North Atlantic overturning and deep-ocean for multi-decadal global-mean-temperature variability, Earth Syst. Dynam., 4, 967-1013, doi:10.5194/esdd-4-967-2013, 2014 b.

SED: UNFCCC: Report on the Structured Expert Dialogue (SED) on the 2013-2015 review, FCCC/SB/2015/INF.1, 2015.
Seneviratne, S. I., Donat, M. G., Pitman, A. J., Knutti, R., and Wilby, R. L.: Allowable $\mathrm{CO}_{2}$ emissions based on regional and impact-related climate targets, Nature, 1870, 1-7, doi:10.1038/nature16542, 2016.

Sillmann, J., Kharin, V. V., Zhang, X., Zwiers, F. W., and Bronaugh, D.: Climate extremes indices in the CMIP5 multimodel ensemble: Part 1. Model evaluation in the present climate, J. Geophys. Res.-Atmos., 118, 1716-1733, doi:10.1002/jgrd.50203, 2013a.

Sillmann, J., Kharin, V. V., Zhang, X., Zwiers, F. W., and Bronaugh, D.: Climate extremes indices in the CMIP5 multimodel ensemble: Part 2. Future climate projections, J. Geophys. Res.-Atmos., 118, 2473-2493, doi:10.1002/jgrd.50188, 2013b.

Sippel, S., Zscheischler, J., Heimann, M., Otto, F. E. L., Peters, J., and Mahecha, M. D.: Quantifying changes in climate variability and extremes: Pitfalls and their overcoming, Geophys. Res. Lett., 42, 9990-9998, doi:10.1002/2015GL066307, 2015.

Smith, K. R., Woodward, A., Campbell-Lendrum, D., Chadee, D., Honda, Y., Liu, Q., Olwoch, J., Revich, B., and Sauerborn, R.: Human Health: Impacts, Adaptation, and Co-Benefits, in: Climate Change 2014: Impacts, Adaptation, and Vulnerability, Contribution of Working Group II to the Fifth Assessment Report of the Intergovernmental Panel on Climate Change, chap. 11, edited by: Field, C. B., Barros, V. R., Dokken, D., Mach, K. J., Mastrandrea, M. D., Bilir, T. E., Chatterjee, M., Ebi, K. L., Estrada, Y., Genova, R., Girma, B., Kissel, E., Levy, A., MacCracken, S., Mastrandrea, P. R., and White, L., Cambridge University Press, Cambridge, UK and New York, NY, USA, 709-754, 2014.

Tai, A. P. K., Martin, M. V., and Heald, C. L.: Threat to future global food security from climate change and ozone air pollution, Nat. Clim. Change, 4, 817-821, doi:10.1038/nclimate2317, 2014.

Taylor, K. E., Stouffer, R. J., and Meehl, G. A.: An Overview of CMIP5 and the Experiment Design, B. Am. Meteorol. Soc., 93, 485-498, doi:10.1175/BAMS-D-11-00094.1, 2011.

Tebaldi, C. and Arblaster, J. M.: Pattern scaling: Its strengths and limitations, and an update on the latest model simulations, Climatic Change, 122, 459-471, doi:10.1007/s10584-013-1032-9, 2014.

Tebaldi, C. and Friedlingstein, P.: Delayed detection of climate mitigation benefits due to climate inertia and variability, P. Natl. Acad. Sci., 110, 17229-17234, doi:10.1073/pnas.1300005110, 2013.

Tebaldi, C., Arblaster, J. M., and Knutti, R.: Mapping model agreement on future climate projections, Geophys. Res. Lett., 38, L23701, doi:10.1029/2011GL049863, 2011.

Teh, L. S. L., Teh, L. C. L., and Sumaila, U. R.: A Global Estimate of the Number of Coral Reef Fishers, PLoS ONE, 8, e65397, doi:10.1371/journal.pone.0065397, 2013.

Timmermann, R. and Hellmer, H. H.: Southern Ocean warming and increased ice shelf basal melting in the twenty-first and twentysecond centuries based on coupled ice-ocean finite-element modelling, Ocean Dynam., 63, 1011-1026, doi:10.1007/s10236-0130642-0, 2013.

UNFCCC - United Nations Framework Convention on Climate Change: Framework Convention on Climate Change, United Nations (UN), New York, 1992.

UNFCCC: Decision 1/CP.21. The Paris Agreement, 2015.

Vaughan, M. M., Huffaker, A., Schmelz, E. A., Dafoe, N. J., Christensen, S., Sims, J., Martins, V. F., Swerbilow, J., Romero, M., Alborn, H. T., Allen, L. H., and Teal, P. E. A.: Ef- 
fects of elevated $\mathrm{CO}_{2}$ on maize defence against mycotoxigenic Fusarium verticillioides, Plant Cell Environ., 37, 2691-2706, doi:10.1111/pce.12337, 2014.

Wada, Y., van Beek, L. P. H., Sperna Weiland, F. C., Chao, B. F., $\mathrm{Wu}$, Y.-H., and Bierkens, M. F. P.: Past and future contribution of global groundwater depletion to sea-level rise, Geophys. Res. Lett., 39, 1-6, doi:10.1029/2012GL051230, 2012.

Warszawski, L., Frieler, K., Huber, V., Piontek, F., Serdeczny, O., and Schewe, J.: The Inter-Sectoral Impact Model Intercomparison Project (ISI-MIP): Project framework, P. Natl. Acad. Sci. USA, 111, 3228-3232, doi:10.1073/pnas.1312330110, 2014.

Werner, A. D., Bakker, M., Post, V. E. A., Vandenbohede, A., Lu, C., Ataie-Ashtiani, B., Simmons, C. T., Barry, D. A.: Seawater intrusion processes, investigation and management: Recent advances and future challenges, Adv. Water Resour., 51, 3-26, doi:10.1016/j.advwatres.2012.03.004, 2013.
Wigley, T. M. L. and Raper, S. C. B.: Extended scenarios for glacier melt due to anthropogenic forcing, Geophys. Res. Lett., 32, L05704, doi:10.1029/2004GL021238, 2005.

Zhang, X., Alexander, L., Hegerl, G. C., Jones, P., Tank, A. K., Peterson, T. C., Trewin, B., and Zwiers, F. W.: Indices for monitoring changes in extremes based on daily temperature and precipitation data, Wiley Interdisciplinary Reviews: Climate Change, 2, 851-870, doi:10.1002/wcc.147, 2011.

Zopa, S., Schulz, Y. B. M., and Cugnet, S. B. D.: Aerosol and ozone changes as forcing for climate evolution between 1850 and 2100, Clim. Dynam., 40, 2223-2250, doi:10.1007/s00382-012-1408-y, 2013. 